\title{
Business Entertainment Expenditure and Stock Price Crashes: The Agency Problem Perspective
}

\author{
Yu Kyung Lee* , Ph.D. Candidate, Seoul National University
}

\begin{abstract}
$\langle$ Abstract $\rangle$
This study examines the effects of corporate entertainment expenditure on stock price crashes. From the trust-building perspective, the formation of relationships through spending on entertainment increases information transparency, increases information flow, and provides an opportunity to gain stakeholder trust, thus lowering the risk of a stock price crash. On the other hand, from the agency problem perspective, entertainment spending is related to information opacity and corporate corruption, increasing the risk of a stock price crash. We find that entertainment spending relates positively to a stock price crash, supporting the agency problem hypothesis. Social networking through entertainment expenditure increases information asymmetry and opacity between network insiders and outsiders. In addition, corporate insiders have an incentive not to disclose negative information, such as an increase in political and legal risks, while exaggerating the benefits of social networking. Consequently, the negative information hidden in the market spills out at once, leading to the stock price crash. We also find that the enactment of the Kim Young-ran Act, which affects entertainment expenses, alleviates the positive effect on the risk of a stock price crash significantly. Through these results, we confirm that the anti-graft law enhances management transparency and improves the information environments surrounding companies.
\end{abstract}

Keywords: Agency Problem; Corporate Entertainment Expenditure; Stock Price Crash; Governance; Social Networking

JEL Classification: G34, G18

* Corresponding Author. Address: Seoul National University, 1, Gwanak-ro, Gwanak-gu, Seoul, Korea 08826; E-mail: yukyung88@snu.ac.kr; Tel: +82-2-880-6854; Fax: +82-2-882-0547.

Received: May 21, 2020; Revised: January 24, 2021; Accepted: February 8, 2021 


\title{
기업의 접대비 지출과 주가 급락위험: 대리인 문제를 중심으로
}

이 유 경 (서울대학교 박사과정)*

\begin{abstract}
본 연구에서는 기업의 접대비 지출이 주가 급락 위험에 미치는 영향을 살펴본다. 만약 접대비 지출을 통한 관계 형성이 기업의 정보 투명성을 증대시키고 정보의 흐름을 원활하게 하여, 이해관계자들의 신뢰를 얻는 기회가 된다면 주가 급락위험은 감소할 수도 있고(신뢰형성 견해), 반대로 만약 관계 형성 비용의 증가가 불투명성과 기업의 부패와 관계가 있다면 주가 급락위험은 증가할 수 있다(대리인 문제 견해). 분석결과, 접대비 지출이 증가할수록 주가 급락위험은 증가하는 것으로 나타났다. 소셜 네트워킹은 네트워크 내부자와 외부자 사이에 정보 비대칭성과 불투명성이 증가시키고, 기업의 내부자는 소셜 네트워킹의 이점과 같은 긍정적인 뉴스는 과장하는 동시에 이와 관련된 정치적·법적 위험이 커지는 것과 같은 부정적 정보는 공개하지 않을 유인을 가지게 되어, 시장에 숨겨져 있던 부정적 정보가 한꺼번에 쏟아져 나와 주가 급락이 증가하게 되는 것이다. 즉, 이러한 결과는 대리인 문제(agency problem) 가설을 지지하는 것이다. 또한, 접대비 지출에 영향을 줄 김영란법의 입법 및 제정으로 인하여 기업의 접대비가 주가 급락 위험에 미치는 양 $(+)$ 의 영향을 유의미하게 감소시킴을 확인하였다. 이러한 결과는 김영란법과 같은 부정청탁금지법이 경영 투명성을 증대시키고 있음을 시사한다.
\end{abstract}

핵심 단어 : 대리인 문제, 접대비 지출, 주가 급락, 지배구조, 소셜 네트워킹

JEL 분류기호: G34, G18

* 연락담당 저자. 주소: 서울특별시 관악구 관악로 1 서울대학교 경영학부 08826; E-mail: yukyung88@snu.ac.kr; Tel: 02-880-6854; Fax: 02-882-0547. 


\section{1. 서론}

우리나라 기업들의 소위 접대로 불리는 관계 형성(relationship-building)을 통한 비즈니스 관행은 오래전부터 고착되어왔다. 그럼에도, 외려 과도한 관계형성비용의 지출은 기업에게 독이 될 수 있다는 점에서 접대를 통한 관계 형성은 양날의 검과 같다. 물론 일반적으로 업무와 관련된 관계 형성 지출이 기업성과에 긍정적인 영향을 미칠 수 있다는 견해에는 이견이 없다. 1 하지만, 이러한 비즈니스 관계 형성 문화가 사회 전반의 부패를 증가시키고,2) 기업의 윤리경영을 어렵게 하는 요인 중 하나이며, 한번 관계 형성 의존 기업이 되어버리면 오히려 기업성과가 악화될 수 있다는 것에 대해서도 이견이 없다.3) 특히나, 국내 법인의 관계 형성을 위한 접대비 지출은 지난 2018년 기준 10 조 원을 넘었을 만큼 그 금액이 상당한 수준이다.4) 따라서 본 연구에서는 우리나라 기업의 중요한 재량적 지출 중 하나에 해당하는 접대비에 대해 살펴보고자 한다. 특히, 관계 형성 비용인 접대비가 기업의 주가 급락위험에 미치는 영향을 조사하고자 한다.

기존연구에 따르면 비용을 수반하는 소셜 네트워킹이 주가 급락위험에 미치는 영향에 대해서는 상반된 견해가 존재한다(Ben et al., 2020). 먼저 신뢰형성(trust-building) 견해에 따르면, 기업활동에 있어 외부 이해 관계자들은 사업 성공을 위해서 매우 중요한 존재이고, 이들과의 끈끈한 유대관계 유지는 필수적이다(Donaldson and Preston, 1995; Freeman, 2010; Freeman et al., 2004). 특히나 한국 사회는 지연, 학연 등으로 이루어진 연줄(connection)을 기반으로 한 사회문화가 형성되어 있다. 따라서 기업들은 접대비 지출을 통해 여러 이해 관계자와 관계를 형성하고 개선함으로 신뢰와 사회적 자본(social capital)을 확보하고, 사업에 대한 정보를 주고받게 된다. 즉, 접대비 지출은 이해 관계자와 더 나은 의사소통 채널을 구축하고 정보 흐름을 방해하지 않고 오히려 증가시켜 정보의 투명성을 높인다(Ben et al., 2020). 주가 급락위험이 공식 채널을 통한 정보전달을 방해하는 경영자의 나쁜 뉴스의 축적에서 비롯된 것임을 고려할 때(Jin and Myers, 2006), 소셜 네트워킹을 포함한 대체적인 비공식 채널을 통해 수집한 정보는 정보에 대한 경영자의 독점을 완화하고 나쁜 뉴스의 축적을 막을 수 있다(Fang et al., 2021). 결과적으로, 더욱더 잘 구축된 소셜 네트워킹을 가진 기업의 주가 급락위험이 그렇지 않은 기업에 비해 낮을 수 있다.5)

1) Choi et al.(2005), Lee(2009), 그리고 Kim and Kim(2011) 등의 연구에서는 접대비 지출이 기업성과 혹은 기업가치에 긍정적인 영향을 미치고 있음을 확인하였다.

2) Chen et al.(2013), Ben et al.(2020), Cai et al.(2011), Fang et al.(2021), Park and Lee(2003), 그리고 $\mathrm{Im}$ and $\operatorname{Kim}(2019)$ 등의 연구에서는 접대비를 뇌물 혹은 부정·부패의 대리변수로 사용하였다.

3) 이전의 연구에서는 부정부패가 자원의 분배를 왜곡하고(Acemoglu and Verdier, 2000; Khwaja and Mian, 2005), 민간 투자에 영향을 미치며, 기업혁신을 방해하기 때문에, 궁극적으로 장기적인 경제 성장과 기업가치를 저해한다고 주장한다(Mauro, 1995).

4) '접대비 규제 풀면 ‘내수' 나아질까?' 2020.04.01. 조세일보.

5) 예를 들어, Fang et al.(2021)에 의해 수행된 최근 실증연구에서는 이사회의 외부 소셜 네트워크 수준이 향후 주가 급락위험과 음의 상관관계가 있음을 발견했다. 
반면에 대리인 문제(agency problem) 견해에 따르면, 일부 이해 관계자와의 긴밀한 관계는 오히려 대리인 문제를 증가시킬 수 있다. 특정 이해 관계자와 지나치게 긴밀한 관계를 맺으면 네트워크 외부의 다른 이해 관계자는 “밀접한 클럽” 내에서 주고받는 비공개 정보에 접근할 수 없다(Granovetter, 1985). 따라서 접대비 지출을 통한 소셜 네트워킹 구축은 관계 네트워크의 내부자와 외부자 사이에 정보 비대칭성과 불투명성을 높인다. 경영자는 소셜 네트워크의 내부자와 외부자 간의 정보 불투명성을 활용하여 정치적 지대추구 및 뇌물 수수와 같이 부패한 접대비 지출을 정상적인 비즈니스 지출로 숨길 유인을 갖는다(Ben et al., 2020). 경영자는 소셜 네트워킹의 이점과 같은 기업의 긍정적인 뉴스는 과장함과 동시에 이와 관련된 정치적 및 법적 위험이 커지는 것과 같은 부정적인 뉴스는 과소평가하거나 의도적으로 은폐하여, 좋은 소식과 나쁜 소식에 대한 비대칭적 처리를 시도한다(Ben et al., 2020, Kothari et al., 2009). 따라서 일부 이해 관계자와 관계가 너무 가까워지면, 불가피하게 네트워크 외부의 주주보다 네트워크 내에서 더 많은 정보를 공유하게 되고, 이렇게 정보가 비대칭인 상황에서는 정보 불투명성이 커져 경영상의 나쁜 뉴스를 저장하는 행위를 촉진하기 때문에 주가 급락의 가능성이 더 커진다 (Hutton et al., 2009; Jin and Myers, 2006; Kim et al., 2011a, 2011b).6)

종합해보면, 만약 기업의 관계 형성을 위한 노력이 기업의 정보 투명성을 증대시키고 정보의 흐름을 원활하게 하여, 이해 관계자들의 신뢰를 얻는 기회가 된다면 주가 급락위험은 감소할 수 있고(신뢰형성 견해), 반대로 만약 관계형성비용의 증가가 정보의 불투명성과 경영자의 긍정적 뉴스와 부정적 뉴스의 비대칭적 처리와 관계가 있다면 주가 급락위험은 증가할 수 있다(대리인 문제 견해). 이처럼 재량적 지출인 접대비를 보는 시각에 따라 상반된 예측이 존재하므로, 본 연구에서는 접대비 지출이 미래 주가 급락위험에 미치는 영향을 조사하여, 접대비 지출의 실질적인 동기를 살펴보고자 한다.

한편, 지난 2015년 접대비와 관련된 제도의 대대적인 변화가 있었다. 학계는 물론 사회적으로도 관심이 많았던 소위 김영란법(부정청탁 및 금품 등 수수의 금지에 관한 법; 이하 김영란법)이 입법 및 제정된 것이다.7) 김영란법의 입법으로 사회적으로는 기업경영의 투명성이 높아지고 부정청탁이 감소 될 것으로 기대되었고 그로 인해 기업의 접대비 지출 양상에 큰 변화를 가져올 것으로 예상되었다.8) 따라서, 김영란법의 입법은 기업의 접대비 지출을 감소시킬 것으로 예상된다.

6) 이러한 견해를 뒷받침하는 실증분석에 따르면, 불투명한 재무보고, 기업의 세금 회피, 그리고 임원의 주식보상은 주가 급락위험과 양의 관계를 가지고 있으며, 반대로 보수주의 회계는 이러한 주가 급락위험을 감소시킨다고 주장한다(Hutton et al., 2009; Kim et al., 2011a, 2011b; Kim and Zhang, 2014).

7) 김영란법의 목적은 동 법 제 1 조에 제시되어 있다. '공직자 등에 대한 부정청탁과 금품 등의 수수를 금지함으로써 공정한 직무수행을 보장하고 공공기관에 대한 국민의 신뢰를 확보하는 것을 목적으로 한다.'

8) "김영란법은 접대 문화가 우리 사회에 뿌리 깊게 배어 있으며 처음으로 기업과 대중에게 문제점을 전달했다는 사실만으로도 의미가 있다. 특히 회계투명성 지수가 세계 최하위권인 우리나라에서 김영란 법이 시사하는 바는 크다. 즉 김영란법의 통과만으로도 투명성지수와 부패지수가 개선됐다는 신호를 전달해 사회적 효용을 증가시킨다.”(‘회계 투명성 높은 사회’ 여는 김영란법, 2016. 08. 29 경향신문). 
한국증권학회지 제 50 권 1 호 (2021)

또한, 김영란법으로 경영 투명성이 증가하고 정보환경이 개선된다면(Choi et al., 2019), 김영란법 시행 이후 접대비 지출이 주가 급락위험에 미치는 영향은 이전과 다른 양상을 보일 수도, 유지할 수도 있다고 예상된다. 특별히, Ben et al.(2020)은 지난 2012년 중국에서 부정부패 척결 캠페인 (anti-corruption campaign)이 진행되었을 때 접대비 지출이 주가 급락에 미치는 유의미한 양의 영향이 유의미하게 감소함을 보이며, 이는 부정부패 척결 캠페인이 기업을 둘러싼 정보환경을 개선 시킨 결과라고 주장하였다. 따라서 본 연구에서는 김영란법의 도입이 접대비 지출과 주가 급락위험 간의 관계에 어떠한 영향을 미치는지 살펴보고자 한다.

주가 급락위험은 기업 정보환경의 변화, 특히 재무적-회계적 투명성과 크게 관련이 있다(Hutton et al., 2009; Kim and Zhang, 2014, 2016; Kim et al., 2011b). 기존의 많은 연구에 따르면, 기업의 정보 불투명성은 주가 급락위험을 증가시키는 것으로 일관되게 보고하고 있다(Hutton et al., 2009; Kim and Zhang, 2014, 2016; Kim et al., 2011b).9) 따라서 본 연구에서도 정보 불투명성을 기준으로 하위표본을 나누어 각각의 경우 접대비 지출과 주가 급락위험의 관계가 서로 다른 양상을 보이는지 조사하고자 한다. 정보가 비대칭인 상황에서는 정보 불투명성이 커져 경영상의 나쁜 뉴스를 저장하는 행위를 촉진하기 때문에 주가 급락의 가능성이 더 커질 수 있다. 따라서 본 연구에서는 기업의 정보 불투명성이 높을수록 접대비 지출과 주가 급락의 관계가 더욱 강하게 나타날 것으로 예상한다.

또한, 우리나라에서 접대비는 재무제표 의무공시 사항이 아니므로 접대비 공시는 선택적으로 이루어질 수 있다. 실제로, 전체표본에서 약 2,423 개의 기업-연도 관측치가 접대비를 분리 공시하지 않고 있어, 상당수 기업이 공시하지 않음을 확인할 수 있다. 국내 상장기업들은 대부분 가족 지분율이 높은 가족 기업에 해당하고, 재벌이라 불리는 대규모기업집단에 속한 기업들도 많다.10) 만약 기업의 내부자가 재량적 비용으로 처리되는 접대비를 자신의 사익추구를 위해서 사용하고자 하고, 지출 수준이 과도하게 크다면 언론이나 외부의 관심을 받을 수 있기에 일부러 공시를 선택적으로 하지 않을 수 있다. 따라서 본 연구에서는 기업들의 접대비 공시가 어떤 요인에 의해서 이루어지는지 분석하고자 한다. 이를 위해 소유구조, 대리인 비용, 기업지배구조, 그리고 기업특성 변수를 포함한 로짓모델을 사용하여 기업의 접대비 공시 가능성을 추정한다.

본 연구에서는 국내 코스피와 코스닥 상장기업을 대상으로 2009년부터 2018년까지의 자료를 이용하여 기업의 접대비 지출이 주가 급락위험에 미치는 영향을 살펴본다. 이를 위해 주가 급락위험의 대리변수인 음(-)의 조건부 왜도(NSKEW)와 하락-상승 변동성(DUVOL)을 사용하고자 한다(Kim and Zhang, 2014; Kim et al., 2011a, 2011b). 분석결과, 기업의 접대비 지출이 증가할수록 주가 급락위험은 증가하는 것으로 나타나, 국내 기업의 접대비 지출은 대리인 문제(agency problem) 가설을 지지하는 것으로 확인되었다. 소셜 네트워킹을 위한 접대비

9) Hutton et al.(2009)과 Kim and Zhang(2014)에서는 기업의 회계적 불투명성(opaqueness)을, Kim and Zhang(2016)에서는 회계적 보수주의를, 그리고 Kim et al.(2011b)에서는 조세회피(tax avoidance)를 정보 불투명성의 대용변수로 사용하여 주가 급락위험에 미치는 영향을 연구하였다.

10) 우리나라 전체기업 중 $80.7 \%$ 는 지배주주 및 그 가족에 의해 소유 및 통제되고 있으며, 전체기업 중 42.6\%는 피라미드식 소유구조를 가지고 있는 기업이다(Claessens et al., 2000). 
지출을 통해 네트워크 내부자와 외부자 사이의 정보 비대칭성이 심해지고(Ben et al., 2020), 경영자는 이를 이용하여 기업의 긍정적인 뉴스는 내보내고 기업의 부정적 정보를 공개하지 않을 유인을 갖지만(Ben et al., 2020; Kothari et al., 2009), 결국 누적된 정보가 어느 임계치에 이르면 한 번에 시장에 쏟아져 나오게 되어 주가 급락이 증가하는 것이다.

아울러, 본 연구에서는 접대비 지출에 영향을 줄 김영란법의 입법 및 제정으로 인하여 기업의 접대비가 주가 급락위험에 미치는 양 $(+)$ 의 영향을 유의미하게 감소시킴을 확인하였다. 이러한 결과를 통해 김영란법과 같은 부정청탁금지법이 경영 투명성을 증대시켜 기업을 둘러싼 정보환경을 개선하고(Choi et al., 2019), 결과적으로 대리인 문제를 감소시키는 효과가 있음을 확인하였다.

다음으로, 기업의 재무적-회계적 불투명성이 주가 급락위험과 크게 관련이 있다는 기존 연구의 결과를 따라서(Hutton et al., 2009; Kim and Zhang, 2014; Kim et al., 2011b), 본 연구에서도 정보 불투명성이 높은 기업과 낮은 기업으로 나누어 접대비가 주가 급락위험에 미치는 영향을 조사하였다. 분석결과를 보면, 정보 불투명성이 낮은 하위그룹에서는 접대비 지출이 주가 급락위험에 미치는 영향은 미미하게 나타났지만, 반대로 정보 불투명성이 높은 하위그룹에서는 접대비 지출이 증가할수록 주가 급락위험이 증가하는 것으로 나타났다. 또한, 기업의 정보 불투명성이 높을수록 김영란법의 효과가 더욱 두드러지게 나타나는 것을 확인하였다. 이러한 결과를 통해 김영란법이 기업의 정보 투명성을 증가시키는 효과를 가지고 있고, 결과적으로 접대비 지출을 통한 대리인 문제를 경감시키는 효과가 있음을 다시 한번 확인하였다.

한편, 의무공시 사항이 아닌 국내 기업의 접대비 분리공시의 결정요인을 살펴보고자 로짓 회귀분석을 진행하였다. 분석결과를 살펴보면, 대규모기업집단에 해당할수록, 외국인 투자자의 지분율이 많을수록 접대비 분리공시를 하지 않는 것으로 나타났다. 반면, 자산회전율이 높을수록, 이사회의 규모가 클수록 접대비 분리공시를 하는 것으로 나타났다. 이러한 결과는 잠재적 대리인 문제가 큰 기업에서는 접대비 분리공시를 하지 않지만, 기업지배구조가 좋고 대리인 문제가 작은 기업일수록 접대비 분리공시를 하고 있음을 시사한다.

본 연구는 다음과 같은 공헌도가 있다. 첫째, 본 논문은 한국 시장을 대상으로 접대비와 주가 급락위험 간의 관계를 실증적으로 분석한 최초의 연구이다. 그동안 국내의 많은 연구에서 접대비 지출이 대리인 문제를 반영하고 있음을 밝혀왔으나, 대부분 기업가치 혹은 기업성과를 이용하여 분석을 진행하였다(Choi et al., 2005; Lee, 2009; Kim and Kim, 2011). 본 연구에서는 이러한 연구를 확장하여, 접대비 지출의 증가로 인해 대리인 문제가 증가함에 따라 주가 급락위험이 증가할 수 있음을 보였다. 이를 통해 본 연구는 접대비가 기업과 투자자에게 미치는 영향에 대한 이해를 넓히고 있다.

둘째, 김영란법의 제정 및 입법으로 인한 기업의 정보환경이 개선되었음을 밝힌 최초의 연구이다. 지난 2015년 제정 및 입법된 김영란법은 한국 사회에 만연하게 퍼져있는 부정한 청탁과 금품수수 등의 관행과 악습을 줄여줄 것으로 기대되었다. 따라서, 기업을 둘러싼 정보환경 역시 투명하게 개선될 것으로 예상되었지만, 이와 관련하여 국내에서 진행된 논문은 거의 전무하다. 본 연구는 김영란법의 입법이 접대비 지출이 주가 급락위험에 미치는 양의 영향을 
한국증권학회지 제 50 권 1호 (2021)

크게 완화함을 보임으로써 기업의 정보환경을 크게 개선 시켜 대리인 문제를 감소시켰다는 근거를 제시하고 있다.

셋째, 본 연구는 미래의 주가 급락위험을 예측하려는 이전의 연구를 확장한다(Chen et al., 2001; Hong and Stein, 2003; Jin and Myers, 2006; Hutton et al., 2009; Kim et al., 2011a, 2011b; Kim and Zhang, 2014). 주가 급락위험은 위험의 비대칭성을 포착하므로 포트폴리오 이론, 자산가격 결정 및 옵션 가격 결정 모델과 관련 있는 주식수익률 분포의 중요한 특성이다. 또한, Harvey and Siddique(2000)는 조건부 왜도가 자산가격 결정에 중요한 요인이라고 제안한다. 따라서 본 연구는 미래의 주가 급락위험을 증가시키는 새로운 요소를 식별함으로써 이전 연구를 확장하고자 한다.

넷째, 국내 기업의 접대비 지출 규모가 상당함에도 불구하고, 손익계산서상 접대비 계정은 의무공시 항목이 아니기에 세부금액을 분리 공시하지 않고 판매관리비로 묵어서 공시하는 기업이 많다.11) 만약 기업의 내부자가 기업의 자원을 유용하여 사익편취를 하고자 한다면, 재량적 비용이자 공시를 하지 않아도 되는 접대비 계정을 사용할 수 있다. 따라서 본 연구에서는 국내 기업들의 접대비 공시의 결정요인을 살펴보고자 하며, 이는 국내 기업들의 접대비 공시의 결정요인을 살펴본 최초의 논문이다.

본 논문의 나머지 부분은 다음과 같이 구성된다. 제 2 장에서는 선행연구와 연구배경을 제시한다. 제 3 장에서는 본 논문의 자료구성과 변수구성에 대해 논의한다. 제 4 장 그리고 제 5 장은 실증 결과를 보고한다. 제 6 장에서는 결론을 제시한다.

\section{2. 선행연구와 연구배경}

\section{1 신뢰형성 관점에서의 접대비와 주가 급락위험에 관한 선행연구}

소셜 네트워킹은 다음과 같은 이유로 경제 활동에 영향을 미치게 된다. 첫째, 사람들은 개인적인 인맥에서 오는 정보를 더 신뢰하는 경향이 있으므로 정보의 흐름과 품질에 영향을 미친다 (Granovetter, 2005). 둘째, 네트워크에서 행위자 간의 반복적인 상호작용은 신뢰와 상호이해를 촉진한다(Granovetter, 2005). 이렇듯, 소셜 네트워킹은 정보 교환을 위한 중요한 통로 역할을 한다. 실제로 일부 연구에서는 공급 업체, 고객, 그리고 기타 사업 동반자와의 만찬과 같은 편안한 환경에서 정보를 쉽게 전송하고 교환할 수 있게 해준다고 주장한다(Cao et al., 2016; Sun, 2016). 즉, 소셜 네트워킹은 정보의 품질과 흐름을 개선하여 정보의 전송을 용이하게 한다(Haythornthwaite, 1996; Jackson et al., 2017). 기존 논문에서는 외부 이해 관계자들과의 소셜 네트워킹을 통한 신뢰 강화와 더욱 긴밀해진 관계로 인한 정보의 증가와 전달은 기업의

11) “실제로 10 대 기업 가운데 올해 반기보고서에서 접대비를 밝힌 곳은 기아차와 한화 등 2 곳에 불과했고, 삼성전자와 현대차, 포스코, LG전자, 한국전력공사, SK하이닉스, GS칼텍스, 현대모비스 등은 공시하지 않았다.”(2019. 9. 29, 매경신문기사). 
신용 등급과 주가수익률 증가에 도움이 되고(Engelberg et al., 2012), 주가 안정성을 개선한다고 주장한다(Jones, 1995). 또한 Cao et al.(2016)과 Li et al.(2017)에서는 신뢰할 수 있는 환경에 있는 중국 기업이 미래의 주가 급락위험을 덜 경험한다는 것을 발견했으며, 이는 경영자를 신뢰할 수 있을 때 상호신뢰가 윤리적 행동을 촉진하고 나쁜 소식을 숨기려는 경영자의 인센티브를 약화시키기 때문이라고 하였다.

기업은 접대비 지출을 통해 여러 이해 관계자와의 네트워킹을 구축하고 더 많은 신뢰와 사회적 자본을 확보한다(Ben et al., 2020). 또한, 신뢰, 사회적 규범, 그리고 기업윤리는 서로 분리될 수 없으며 상호 강화되는 특징이 있다(Brenkert, 1998). 이러한 상호주의의 사회적 규범 하에서 소셜 네트워크는 보상과 처벌의 주요 원천역할을 한다(Fang et al., 2021). 즉, 접대비 지출은 네트워킹과 신뢰로 구성되며, 경영자는 사회적 규범에 따라 “올바른 일”을 하며 숨길 것이 없어야 한다.

이러한 맥락에서 접대비 지출은 이해 관계자와 더 나은 의사소통 채널을 구축하고 정보 흐름을 방해하지 않고 오히려 증가시켜 정보의 투명성을 높인다(Ben et al., 2020). 또한 주가 급락위험이 공식 채널을 통한 정보전달을 방해하는 경영자의 나쁜 뉴스의 축적에서 비롯된 것임을 감안 할 때(Jin and Myers, 2006), 소셜 네트워킹을 포함한 대체적인 비공식 채널을 통해 수집 한 정보는 정보에 대한 경영자의 독점을 완화하고 나쁜 뉴스의 축적을 막을 수 있다(Fang et al., 2021). 결과적으로, 더욱더 잘 구축된 소셜 네트워킹을 가진 기업의 주가 급락위험이 그렇지 않은 기업에 비해 낮을 수 있다.

이와 관련된 대표적인 연구인 Fang et al.(2021)의 실증적 연구에서는 이사회의 외부 소셜 네트워크 수준은 미래의 주가 급락위험과 음의 상관관계를 갖는 것으로 나타났다. 이는 외부 네트워킹이 개선되면 정보 전송이 용이해지고 경영상 나쁜 뉴스 비축이 억제되기 때문이라고 설명한다. 또한, Ben et al.(2020)에서는 접대비 지출을 통해 여러 이해 관계자와의 관계가 개선되면 이해 관계자 간의 신뢰도가 높아지고 신뢰할 수 있는 이해 관계자 간에서 발생하는 향상된 정보 풍부성과 투명성은 정보 흐름을 촉진하여 미래의 주가 급락위험을 낮출 수 있다고 언급한다.

\section{2 대리인 비용 관점에서의 접대비와 주가 급락위험에 관한 선행연구}

자원 배분의 측면에서 바라본다면, 접대를 통한 부정청탁은 사회적 자원이 구성원들 사이에 공정하게 배분되는 것을 방해한다. 부정청탁으로 이득을 본 구성원이 있다면, 반대로 받아야 할 사회적 자원을 배분받지 못하여 손해를 입는 구성원이 존재한다. 특히나, 한국기업들은 상당한 규모의 접대비를 지출하면서 인맥 형성에 힘써 왔다(Yoon and Hyeon, 2020). 이러한 기업들은 여러 이해 관계자와 좋은 관계를 유지하기 위해 노력해왔고, 인맥 형성을 위한 방법의 하나로 공무원, 정치인, 언론인뿐 아니라 공급 업체, 고객 등과 같은 사업 동반자 등에게 접대 활동을 활용하였다.

사회학 문헌에 따르면 특정 이해 관계자와 지나치게 긴밀한 관계를 맺으면 네트워크 외부의 다른 이해 관계자가 “밀접한 클럽” 내에서 전송된 비공개 정보에 접근할 수 없다(Granovetter, 
한국증권학회지 제 50 권 1 호 (2021)

1985). 이렇듯, 대리인 비용 관점에서 일부 이해 관계자와의 긴밀한 관계는 대리인 문제를 증가시킬 수 있다. 소셜 네트워킹 구축에 더 많은 지출을 하는 기업은 관계 네트워크의 내부자와 외부자 사이에 더 큰 정보 비대칭성과 불투명성을 나타내기 때문이다(Ben et al., 2020). 이러한 행동은 더 나은 재무 성과를 나타내기 위한 이익관리 전략을 동반할 수 있다. 예를 들어 Liu(2016)는 부패한 관리자가 이익 관리, 내부자 거래, 그리고 사기성 보고(fraudulent reporting)에 참여할 가능성이 더 크다는 것을 보여준다. 또한, 접대비 지출은 본질적으로 비노출성 성격으로 은폐되어, 재무보고의 투명성을 저해하는 이익관리와 관련이 있는 것으로 보고되고 있다(Leuz et al., 2003; Gopalan and Jayaraman, 2012).

이러한 관점에서 볼 때, 기업의 경영자는 소셜 네트워크의 내부자와 외부자 간의 정보 불투명성을 활용하여 정치적 지대추구와 뇌물 수수와 같이 부패한 접대비 지출을 정상적인 비즈니스 지출로 숨길 유인을 갖는다(Ben et al., 2020). 이러한 행위는 주주로부터 다른 이해 관계자에게 부를 이전하고 잠재적으로 기업의 장기 성장 기회를 위태롭게 한다. 또한, 경영자는 소셜 네트워킹의 이점과 같은 기업의 긍정적 정보는 과장함과 동시에 이와 관련하여 정치적 및 법적 위험이 커지는 것과 같은 부정적인 정보는 과소평가하거나 의도적으로 은폐하여, 좋은 소식과 나쁜 소식에 대해 비대칭적 처리를 시도한다(Ben et al., 2020). 비슷한 맥락으로, Kothari et al.(2009)에 따르면 내부자들은 보상체계나 자신들의 경력 관리 등을 위해 주가를 될 수 있으면 높게 유지하려는 유인이 있고, 따라서 기업에 대한 부정적인 뉴스를 외부에 공시하지 않으려 한다. 따라서 일부 이해 관계자와 관계가 너무 가까워지면 불가피하게 네트워크 외부의 주주보다 네트워크 내에서 더 많은 정보를 공유하게 되고, 정보가 비대칭인 상황에서는 정보 불투명성이 커져 경영상의 나쁜 뉴스를 저장하는 행위를 촉진하기 때문에 주가 급락의 가능성이 더 커진다(Hutton et al., 2009; Jin and Myers, 2006; Kim et al., 2011a, 2011b).

\section{3 김영란법의 특성 및 관련 선행연구}

Choi et al.(2019)에서는 김영란법이 시행된 2016년에는 2015년에 비해 세법상 접대비 한도를 초과하여 사용하는 기업에서 주로 접대비의 수익 관련성이 증가하였음을 확인하였다. 이는 접대비 지출이 큰 기업에서의 접대비 지출에 대한 내부통제와 투명성을 강화시키고 업무 관련성이 낮은 접대비 지출을 감소시켜 수익 관련성을 높이는 행태변화를 유도하였음을 의미한다. 또한 Im and Kim(2019)에서는 접대비를 뇌물의 대리변수로 사용하여 기업성과에 미치는 영향을 조사하였는데, 기업의 뇌물 수수 활동 수준이 높을수록 기업성과에 부정적인 영향이 있음을 확인하였다. 또한 이들은 기업의 뇌물 수수를 제한하는 외생적 충격인 김영란법이 제정됨에 따라 이러한 접대비를 절감시킨 기업은 실적이 크게 개선됨을 보여, 뇌물이 기업의 성과를 저해한다는 실증적 증거를 제시하였다. 이는 다시 말해, 김영란법의 제정이 기업의 뇌물 수수를 감소시켰으며, 이는 결과적으로 기업성과를 증가시킴을 보여주는 결과라 할 수 있다. 이러한 결과들은, 김영란법의 시행으로 기업의 정보환경이 개선되었으며, 기업의 성과도 향상되었음을 보여준다. Choi and $\operatorname{Kim}(2017)$ 에서는 김영란법의 도입은 기업의 접대 활동이 건전하고 투명한 기업활동을 저해할 수 있다는 점을 중대하게 인식한 결과로 보이며, 아울러 기업의 접대 활동에서 
Business Entertainment Expenditure and Stock Price Crashes

파급될 수 있는 폐단을 통제하여 대외적인 기업경영의 투명성 및 신인도를 제고 하려는 조치로 볼 수 있다고 언급한다.

한편, Ben et al.(2020)은 한국의 김영란법과 유사한 중국의 부정부패 척결 캠페인(anticorruption campaign)이 진행되었을 때 접대비 지출이 주가 급락에 미치는 유의미한 양의 영향이 유의미하게 감소함을 보이며, 이는 반부패 캠페인은 접대비 지출의 정보 투명성을 개선한 결과라고 설명한다.

\section{3. 표본과 연구모형}

\section{1 표본}

본 연구에서는 2009년부터 2018년을 연구대상 기간으로 하고 한국거래소에 상장된 비금융 제조업 기업만을 표본의 대상으로 한다. 또한, 재무 및 회계, 주가 자료가 공표되어 이용 가능하며 자본잠식이 없는 기업만을 대상으로 한다. 표본기업의 재무 및 회계자료와 대주주 1 인과 특수 관계자의 지분율 자료는 한국 상장회사협의회(Korea Listed Company Association: KLCA)의 TS-2000을 통해 추출하였으며, 주가자료는 FNGuide를 이용하여 추출하였다. 분석자료의 극단치 영향을 배제하기 위하여 상·하위 $1 \%$ 를 제외시켰다.

\section{2 주가급락위험}

본 연구에서는 기존 연구에 따라 주가 급락위험의 대리변수로 음(-)의 조건부 왜도 값(NSKEW)과 하락-상승 변동성(DUVOL)을 사용하고자 한다(Chen et al., 2001; Hong and Stein, 2003; Jin and Myers, 2006; Hutton et al., 2009; Kim et al., 2011a, 2011b; Kim and Zhang, 2014; Piotroski and Roulstone, 2004). 주가 급락위험을 측정하기 위해서는 먼저 기업 고유 주별 주식수익률(firm-specific weekly return)을 계산해야 한다. 이를 위해, 아래 확장된 시장모형 회귀식 (1)을 이용하여 잔차 $\left(\epsilon_{i, w}\right)$ 를 구한다.

$$
R E T_{i, w}=\alpha+\beta_{1} M_{K R E T_{w}}+\beta_{2} M_{K R E T_{w-1}}+\beta_{3} I N D R E T_{i, w}+\beta_{4} I N D R E T_{i, w-1}+\epsilon_{i, w}
$$

여기서, $R E T_{i, w}$ 는 기업 $\mathrm{i}$ 의 주별 주식수익률을 의미하고, $M K R E T_{i, w}$ 은 가치 가중 시장 수익률 (KOSPI/KOSDAQ 지수)을 의미하며, $I N D R E T_{i, w}$ 는 기업 $\mathrm{i}$ 가 속한 한국표준산업분류(KSIC)의 중분류 산업의 가치 가중 수익률을 의미한다. 위의 식을 통해 구해진 잔차에 1 을 더하고 자연로그를 취해서 기업 고유 주별 주식수익률을 계산한다. 즉, 기업 $\mathrm{i}$ 의 주 $\mathrm{w}$ 의 기업 고유 주별 주식수익률은 $\ln \left(1+\epsilon_{i, w}\right)$ 로 정의된다.

$\mathrm{NSKEW}$ 는 기업 고유 주별 주식수익률의 음(-)의 조건부 왜도 값으로, 기업 고유 주별 주식수익률 $\left(\ln \left(1+\epsilon_{i, w}\right)\right)$ 을 이용하여 아래 식을 통해 계산된다(Chen et al., 2001; Kim et al., 2011). 
한국증권학회지 제 50 권 1 호 (2021)

$$
\text { Nskew }_{i, t}=-\left[n(n-1)^{3 / 2} \sum W_{i, t}^{3}\right] /\left[(n-1)(n-2)\left(\sum W_{i, t}^{2}\right)^{3 / 2}\right]
$$

여기서, n은 t년도 동안의 총 거래주 수를 나타낸다. NSKEW는 값이 클수록 수익률의 분포가 보다 왼쪽으로 치우쳐져 있음을 의미하고, 이는 이 값이 커질수록 주가 하락 시 극단 현상이 발생할 가능성, 즉 주가 급락위험이 커진다고 해석할 수 있다.

또한, 하락-상승 변동성(DUVOL)은 주식수익률의 상승 변동성 대비 하락 변동성의 비율이다. 하락-상승 변동성(DUVOL)을 구하기 위해서는 기업 고유 주별 주가수익률 $\left(\ln \left(1+\epsilon_{i, w}\right)\right)$ 을 이용하여 연평균 수익률을 기준으로 하락주(down week; 연평균 수익률 이하)와 상승주(up week; 연평균 수익률 초과)로 구분한다. 그런 다음, 상승주의 표준편차 대비 하락주의 표준편차의 비율에 자연로그를 취해 변동성 차이를 계산한다. 이렇게 계산된 값이 커질수록 주가 하락 시기의 변동성이 상승 시기의 변동성에 비해 더 높음을 의미하므로, 그만큼 주가 급락위험이 큰 것으로 해석할 수 있다(Chen et al., 2001).

$$
\text { Duvol }=\ln \left[\left(\left(n_{u}-1\right) \sum_{\text {down }} W_{i, w}^{2}\right) /\left(\left(n_{d}-1\right) \sum_{u p} W_{i, w}^{2}\right)\right]
$$

\section{3 실증분석 모형}

본 논문에서는 기업의 접대비 지출이 주가 급락위험에 어떠한 영향을 미치는지를 실증적으로 분석하고자 한다. 이를 위해, 아래와 같은 회귀모형을 사용한다(Kim et al., 2011a, 2011b; Chen et al., 2001, Ben et al., 2020). 이때, 강건성 있는 표준오차(Standard error)를 얻기 위해 군집 회귀분석(Cluster Regression)을 사용하여 실증분석을 실시하였다(Petersen, 2009).12)

$$
\begin{aligned}
\text { NSKEW }_{t+1} \text { or } \text { DUVOL }_{t+1}= & \beta_{0}+\beta_{1} \text { BEESALES }_{i, t}+\beta_{2} \text { NSKEW }_{i, t}+\beta_{3} L E V_{i, t} \\
& +\beta_{4} \text { SIZE }_{i, t}+\beta_{5} M B_{i, t}+\beta_{6} \text { RET }_{i, t}+\beta_{7} \text { STD }_{i, t} \\
& +\beta_{8} \text { DTURN }_{i, t}+\beta_{9} A B A C C_{i, t}+\beta_{10} \text { ROA }_{i, t} \\
& +\beta_{11} \text { BOARDSIZE }_{i, t}+\beta_{12} \text { OUTSIDERATIO }_{i, t} \\
& +\beta_{13} \text { Indusrtydummy } \beta_{14} \text { Yeardummy }_{\epsilon}
\end{aligned}
$$

본 연구에서는 손익계산서상의 접대비를 총매출액으로 나눈 값(BEE_SALES)을 주된 설명변수로 사용한다. 기존의 많은 연구에서 접대비를 사적 소비 수준의 대용치로 보고 있으며, 이는 결국 기업 내부자와 외부자 사이의 대리인 비용(agency cost)을 측정하는 추정치가 될

12) Petersen(2009)에서는 개별기업별 효과(firm effect)로 인하여 발생할 수 있는 잔차 의존도 (residual dependence)에 의한 표준오차 편향문제를 완화하기 위해서 개별기업 수준(firm-level)으로 표준오차를 추정해야 한다고 주장하였다. 따라서 본 연구의 분석대상 수준은 개별기업 단위(firm level)이므로 개별기업 단위로 표본의 군집성(cluster)을 통제하였다. 
Business Entertainment Expenditure and Stock Price Crashes

수 있다(Park et al., 2004; Kim and Kim, 2011; Woo, 2015; Morck and Nakamura, 2003; Yafeh and Yosha, 2003).

아울러, 본 논문에서는 주가 급락위험에 영향을 미칠 것으로 알려진 기업특성을 통제하기 위하여 다양한 통제변수를 모든 회귀분석에 포함하였다(Kim et al., 2011a, 2011b; Chen et al., 2001; Ben et al., 2020). 본 연구에서는 통제변수로 음(-)의 조건부 왜도(NSKEW), 레버리지(LEV), 기업 규모(SIZE), 장부가 대비 시장가(MB), 기업 고유 주별 주식수익률의 평균(RET), 기업 고유 주별 주식수익률의 표준편차(STD), 주식회전율의 차이(DTURN), 재량적 발생액의 절댓값 $(\mathrm{ABACC})$, 기업성과 $(\mathrm{ROA})$ 등을 사용한다. 한편, 접대비 지출이 내부자의 사적이익 추구를 위한 재량적 지출이라면 접대비 지출과 주가 급락위험 간의 관계는 기업지배구조에 의해 영향을 받을 수 있다. 따라서 일반적인 주가 급락위험과 관련된 연구에서 사용한 통제변수 외에도 기업지배구조와 관련된 통제변수인 이사회 규모(BOARD_SIZE)와 사외이사 비율(OUTSIDE_RATIO)도 통제변수에 포함한다(Ben et al., 2020). 이와 함께 산업 고정효과와 연도별 고정효과도 함께 통제한다.

또한, 김영란법의 도입이 접대비 지출과 주가 급락위험 간의 관계에 어떠한 영향을 미치는지 살펴보기 위해, 아래와 같이 김영란법 제정 및 입법 이후(2015) 연도에는 1의 값을, 이전 연도에는 0 의 값을 부여한 더미 변수(AFTER)를 포함한 회귀식을 이용한다.13) 접대비(BEE_SALES)와 김영란법의 도입(AFTER)의 교차항을 포함한 회귀분석을 실시한다.

$$
\begin{aligned}
\text { NSKEW }_{t+1} \text { or } \text { DUVOL }_{t+1}= & \beta_{0}+\beta_{1} \text { BEESALES }_{i, t}+\beta_{2} \text { BEE SALES }_{i, t} \times \text { AFTER }_{i, t} \\
& +\beta_{3} \text { AFTER }_{i, t}+\beta_{2} \text { NSKEW }_{i, t}+\beta_{3} \text { LEV }_{i, t}+\beta_{4} \text { SIZE }_{i, t} \\
& +\beta_{5} M B_{i, t}+\beta_{6} \text { RET }_{i, t}+\beta_{7} \text { STD }_{i, t}+\beta_{8} D T U R N_{i, t} \\
& +\beta_{9} \text { ABACC }_{i, t}+\beta_{10} \text { ROA }_{i, t}+\beta_{11} \text { BOARDSIZE }_{i, t} \\
& +\beta_{12} \text { OUTSIDERATIO }_{i, t}+\beta_{13} \text { Indusrtydummy } \\
& +\beta_{14} \text { Yeardummy }+\epsilon_{i, t}
\end{aligned}
$$

<표 1>에는 본 연구에서 사용된 주된 변수들의 정의가 정리되어 있다.

13) 김영란법은 2015년 3월 3일 국회 본회의를 통과했고, 같은 해 3월 27일 법안이 공포되었고, 법 공포 후 1 년 6 개월의 유예기간을 가진 후 2016년 9월 28일부터 시행되었다. 하지만, 대부분의 기업들은 국회 법안이 공포된 이후부터 바로 김영란법에 대비한 것으로 파악된다. 실제로, 월간조선 2015년 2 월 기사 <'김영란법' 제정 앞두고 기업들 초긴장>에 따르면, 이미 기업 내 대관업무를 하는 담당자들은 입법이 논의되던 시기부터 이에 대한 대비를 하고 있는 것으로 알려졌다. 또한 지난 2015년 2월 전경련에서는 김영란법의 입법동향과 이 법안이 기업활동에 미치는 영향에 대해 살펴보고 기업들의 대처 방안을 공유하는 윤리경영임원협의회를 개최하는 등 기업의 대비책 강구를 위해 노력하였다 (CBS 2015년 2월 기사 <김영란법, 기업도 대비해야한다>). 따라서 본 연구에서는 김영란법이 기업의 의사결정 및 내부자의 행동에 영향을 미치는 시기를 제정 및 공포가 확정된 2015년으로 설정하였다. 한편, 김영란법의 도입 시기를 2016년으로 설정하고 분석한 결과에서도 본 연구의 결과와 대동소이하게 나타났다. 
한국증권학회지 제 50 권 1 호 (2021)

〈표 1〉변수정의

이 표에는 동 연구에서 사용된 변수의 정의가 제시되어 있다.

\begin{tabular}{|c|c|}
\hline 변수 & 정의 \\
\hline NSKEW $_{t+1}$ & $\mathrm{t}+1$ 기의 기업고유 주별 주가수익률의 왜도측정치에 (-)를 곱한 값 \\
\hline DUVOL $_{t+1}$ & $\begin{array}{l}\mathrm{t}+1 \text { 기의 기업고유 주별 주가수익률의 상승변동성 대비 하락변동성의 자연 로그를 } \\
\text { 취한 값 }\end{array}$ \\
\hline BEE_SALES & 기업의 관계 형성 비용에 해당하는 접대비를 총매출액으로 나눈 값 \\
\hline BEE_ASSETS & 기업의 관계 형성 비용에 해당하는 접대비를 총자산으로 나눈 값 \\
\hline NSKEW & $\mathrm{t}$ 기의 기업고유 주별 주가수익률의 왜도측정치에 (-)를 곱한 값 \\
\hline LEV & 총부채를 총자산으로 나눈 값 \\
\hline SIZE & 시가총액에 자연로그를 취한 값 \\
\hline $\mathrm{MB}$ & 시장가치 자본을 장부가치 자본으로 나눈 값 \\
\hline RET & 연도별로 계산한 기업고유 주별 주가수익률의 평균에 100을 곱한 값 \\
\hline STD & 연도별로 계산한 기업고유 주별 주가수익률의 표준편차 \\
\hline DTURN & $\begin{array}{l}\mathrm{t} \text { 년도의 월평균 주식회전율(거래량/기말발행주식수)에서 } \mathrm{t}-1 \text { 년도의 월평균 } \\
\text { 주식회전율(거래량/기말발행주식수)을 차감한 값 }\end{array}$ \\
\hline $\mathrm{ABACC}$ & 수정 존스 모형(Dechow et al., 1995)에 따라 측정한 재량적 발생의 절댓값 \\
\hline $\mathrm{ROA}$ & 영업이익을 총자산으로 나눈 값 \\
\hline BOARD_SIZE & 전체 이사회 수에 자연로그를 취한 값 \\
\hline OUTSIDE_RATIO & 전체 이사회에서 사외이사가 차지하는 비율 \\
\hline STD_ACC & Dechow and Dichev(2002)의 방법에 따라 측정한 발생액의 질(accruals quality) \\
\hline BIG4 & $\begin{array}{l}\text { 외부감사인이 빅 } 4 \text { 에 해당하는 경우 } 1 \text { 의 값을, 그렇지 않은 경우 } 0 \text { 의 값을 갖는 } \\
\text { 더미 변수 }\end{array}$ \\
\hline CH_DUM & $\begin{array}{l}\text { 대규모기업집단에 해당하는 경우 } 1 \text { 의 값을, 그렇지 않은 경우 } 0 \text { 의 값을 갖는 더미 } \\
\text { 변수 }\end{array}$ \\
\hline FORE & 외국인 투자자 지분율의 합 \\
\hline OWN & 대주주 1 인과 특수관계자 지분율의 합 \\
\hline
\end{tabular}

\section{4. 실증분석 결과}

\section{1 기초통계}

<표 2>에는 본 연구에서 사용된 변수의 기초통계량이 제시되어 있다. 먼저, 본 연구의 주된 종속변수인 음 $(-)$ 의 조건부 왜도 값 $\left(\mathrm{NSKEW}_{\mathrm{t}+1}\right)$ 을 보면, 평균값은 -0.4196 이고, 중앙값은 -0.4000 이며, 최솟값은 -2.8960 으로 나타났다. 또 다른 종속변수인 하락-상승 변동성 $\left(\mathrm{DUVOL}_{\mathrm{t}+1}\right)$ 의 경우, 평균값은 -0.2107 이고, 최솟값은 -1.0661 , 최댓값은 1.2458 로 나타났다. 또한, 접대비 지출액을 보면 평균은 3억 3,300만 원으로 나타났고, 최솟값은 500 만 원, 최댓값은 29 억 9,800 만 원으로 나타났다. 주된 설명변수인 접대비를 총매출액으로 나눈 값(BEE_SALES)의 평균값은 0.0039 이고, 중앙값은 0.0018 이며, 최댓값은 0.0368로 나타났다. 또 다른 설명변수인 접대비를 총자산으로 나눈 값(BEE_ASSETSS)을 살펴보면, 평균값은 0.0022 고, 중앙값은 0.0013 으로 나타났다. 부채비율 $(\mathrm{LEV})$ 은 범위가 0.0332 에서 0.9319 로 나타났고 평균값은 0.3977 , 중앙값은 
Business Entertainment Expenditure and Stock Price Crashes

0.3916으로 나타났다. 장부가 대비 시장가 비율 $(\mathrm{MB})$ 은 0.2035 에서 10.2091의 범위를 가지고 있으며 평균값은 1.6016으로 확인되었다. 수익성 $(\mathrm{ROA})$ 은 범위가 -0.3136 에서 0.2189 로 나타났고, 평균값은 0.0231로 나타났다. 또한, 사외이사 비율(OUTSIDE_RATIO)은 평균값이 0.3154 로, 최솟값은 0.0000 으로 그리고 최댓값은 1.0000 으로 나타났다.

\section{〈표 2〉기초통계}

이 표에는 동 연구에서 사용된 변수의 기초통계량이 제시되어 있다. $\mathrm{NSKEW}_{\mathrm{t}+1}$ 는 $\mathrm{t}+1$ 기의 기업 고유 주별 주가수익률의 왜도측정치에 (-)를 곱한 값을 의미한다. $\mathrm{DUVOL}_{\mathrm{t}+1}$ 은 $\mathrm{t}+1$ 기의 기업 고유 주별 주식수익률의 상승변동성 대비 하락변동성의 자연로그를 취한 값이다. $\mathrm{BEE}$ 는 손익계산서상 접대비 계정이다. BEE_SALES는 기업의 관계 형성 비용에 해당하는 접대비를 총매출액으로 나눈 값이고, BEE_ASSETS은 기업의 관계 형성 비용에 해당하는 접대비를 총자산으로 나눈 값이다. NSKEW는 t기의 기업 고유 주별 주가수익률의 왜도측정치에 (-)를 곱한 값이다. LEV는 총부채를 총자산으로 나눈 값이고, SIZE는 시가총액에 자연로그를 취한 값이다. $\mathrm{MB}$ 는 시장가치 자본을 장부가치 자본으로 나눈 값이다. RET는 연도별로 계산한 기업 고유 주별 주가수익률의 평균에 100 을 곱한 값이다. STD는 연도별로 계산한 기업 고유 주별 주가수익률의 표준편차이다. DTURN은 t년도의 월평균 주식회전율(거래량/ 기말발행주식수)에서 $\mathrm{t}-1$ 년도의 월평균 주식회전율을 차감한 값이다. ABACC는 수정 존스 모형(Dechow et al., 1995)에 따라 측정한 재량적 발생액의 절댓값이다. ROA는 영업이익을 총자산으로 나눈 값이다. BOARD_SIZE는 전체 이사회 수에 자연로그를 취한 값이고, OUTSIDE_RATIO는 전체 이사회에서 사외이사가 차지하는 비율이다. STD_ACC는 Dechow and Dichev(2002)의 방법에 따라 측정한 발생액의 질(accruals quality)이다. BIG4는 외부감사인이 빅4에 해당하는 경우 1 의 값을, 그렇지 않은 경우 0 의 값을 갖는 더미 변수이다. CH_DUM은 대규모기업집단에 해당하는 경우 1 의 값을, 그렇지 않은 경우 0 의 값을 갖는 더미 변수이다. FORE는 외국인 투자자 지분율의 합이고, $\mathrm{OWN}$ 은 대주주와 특수관계자 지분율의 합이다.

\begin{tabular}{|c|c|c|c|c|c|c|}
\hline & COUNT & MEAN & $\mathrm{SD}$ & MIN & $\mathrm{P} 50$ & MAX \\
\hline NSKEW $_{\mathrm{t}+1}$ & 13,297 & -0.4196 & 0.8866 & -2.8960 & -0.4000 & 2.8596 \\
\hline DUVOL $_{t+1}$ & 13,297 & -0.2107 & 0.3878 & -1.0661 & -0.2280 & 1.2458 \\
\hline BEE (mil.) & 13,297 & 333 & 479 & 5 & 178 & 2998 \\
\hline BEE_SALES & 13,297 & 0.0039 & 0.0059 & 0.0001 & 0.0018 & 0.0368 \\
\hline BEE_ASSETS & 13,297 & 0.0022 & 0.0028 & 0.0000 & 0.0013 & 0.0171 \\
\hline NSKEW & 13,291 & -0.4653 & 0.7806 & -2.8299 & -0.4147 & 1.8606 \\
\hline LEV & 13,297 & 0.3977 & 0.2062 & 0.0332 & 0.3916 & 0.9319 \\
\hline SIZE & 13,297 & 25.2714 & 1.2353 & 22.8331 & 25.1155 & 29.3938 \\
\hline $\mathrm{MB}$ & 13,297 & 1.6016 & 1.5921 & 0.2035 & 1.0922 & 10.2091 \\
\hline RET & 13,297 & -0.2261 & 0.2423 & -1.3618 & -0.1422 & -0.0141 \\
\hline STD & 13,297 & 0.0605 & 0.0295 & 0.0170 & 0.0537 & 0.1637 \\
\hline DTURN & 13,297 & 0.0000 & 0.0092 & -0.0524 & -0.0000 & 0.0479 \\
\hline ABACC & 13,297 & 0.0744 & 0.0884 & 0.0000 & 0.0461 & 0.5244 \\
\hline $\mathrm{ROA}$ & 13,297 & 0.0231 & 0.0831 & -0.3136 & 0.0292 & 0.2189 \\
\hline BOARD_SIZE & 12,915 & 1.6614 & 0.3877 & 0.0000 & 1.6094 & 4.8283 \\
\hline OUTSIDE_RATIO & 12,915 & 0.3154 & 0.1939 & 0.0000 & 0.3750 & 1.0000 \\
\hline BIG4 & 13,297 & 0.3699 & 0.4828 & 0.0000 & 0.0000 & 1.0000 \\
\hline INFORM_DUM & 13,297 & 0.1401 & 0.3471 & 0.0000 & 0.0000 & 1.0000 \\
\hline STD_ACC & 13,241 & 0.1134 & 0.0901 & 0.0155 & 0.0858 & 0.4844 \\
\hline CH_DUM & 13,297 & 0.0976 & 0.2968 & 0.0000 & 0.0000 & 1.0000 \\
\hline FORE & 13,297 & 0.0571 & 0.1030 & 0.0000 & 0.0155 & 0.9968 \\
\hline OWN & 13,292 & 0.3931 & 0.1723 & 0.0000 & 0.3860 & 1.0000 \\
\hline
\end{tabular}




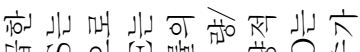

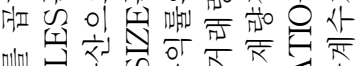

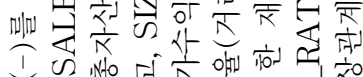

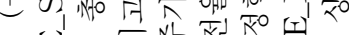

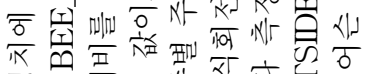

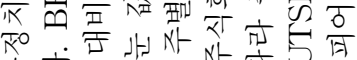

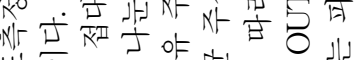

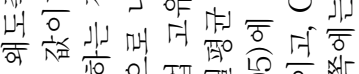

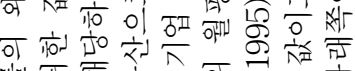

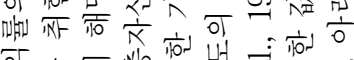
б. 내에

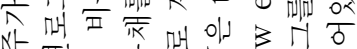

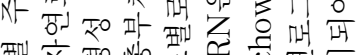

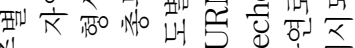

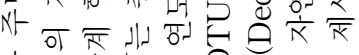

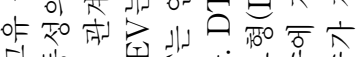

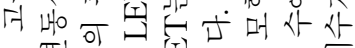

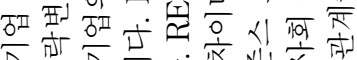

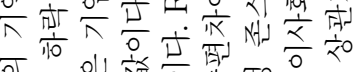

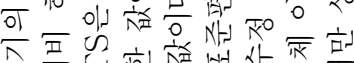

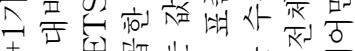
〈F

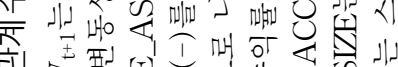

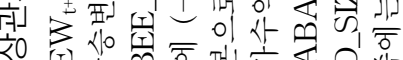

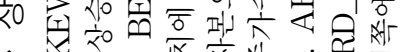

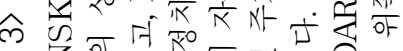

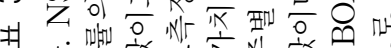

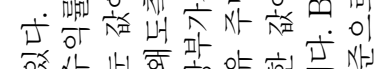

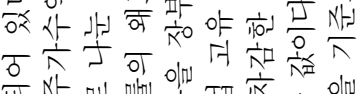

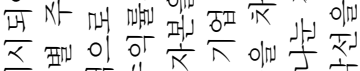

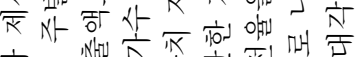

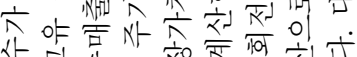

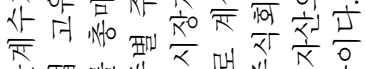

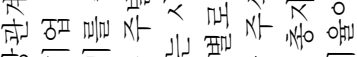

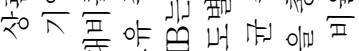

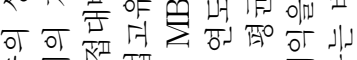

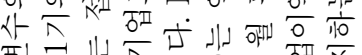

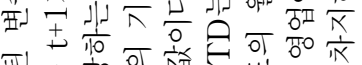

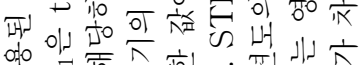

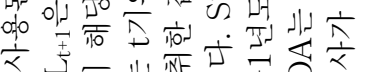

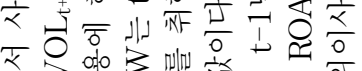

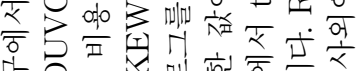

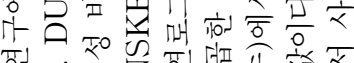
ए人

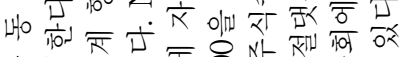

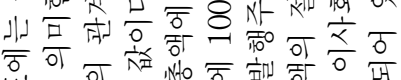

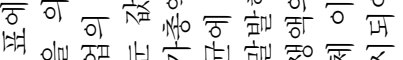

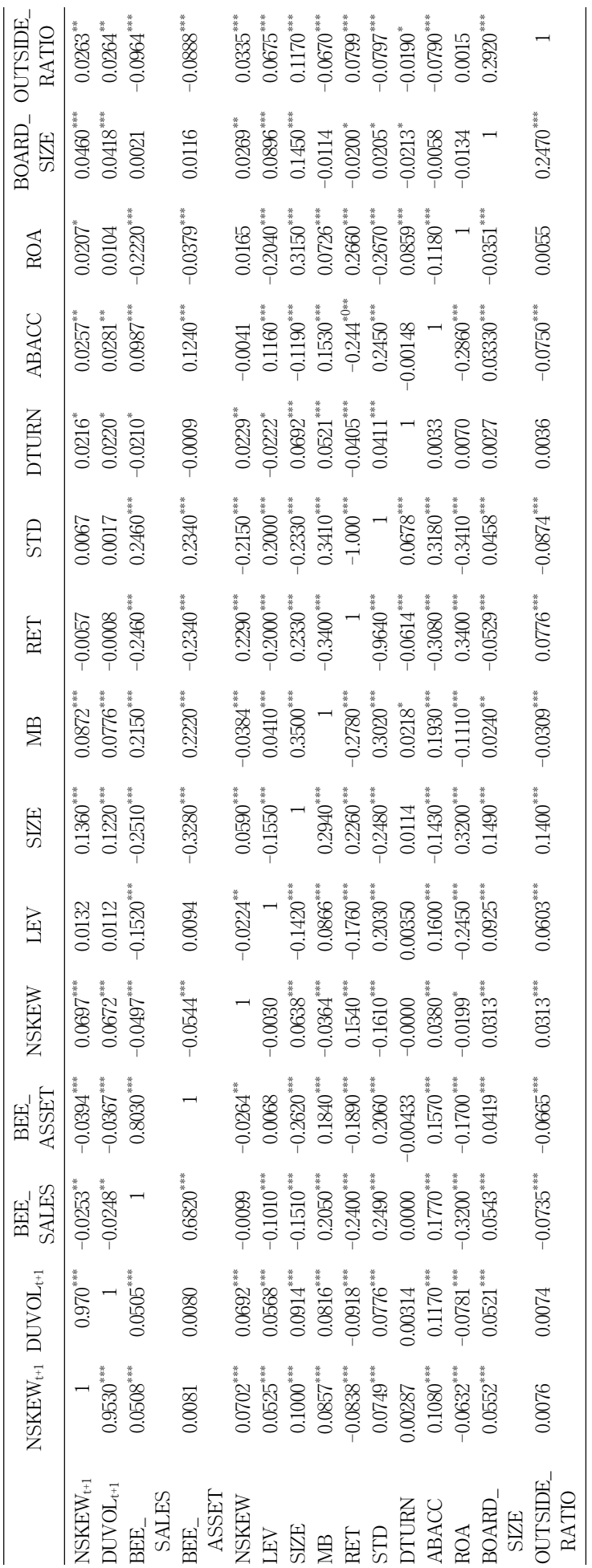


Business Entertainment Expenditure and Stock Price Crashes

또한 <표 3>에는 분석에 사용된 주요 변수들에 대한 피어슨 상관계수가 제시되어 있다. 변수들 사이의 주요 상관관계는 다음과 같다. 먼저, 주가 급락위험의 대리변수인 음(-)의 조건부 왜도 값 $\left(\mathrm{NSKEW}_{\mathrm{t}+1}\right)$ 과 하락-상승 변동성 $\left(\mathrm{DUVOL}_{\mathrm{t}+1}\right)$ 은 유의미한 양의 상관관계를 갖고 있으며 그 값이 0.9530으로 매우 높게 나타났다. 다음으로 음(-)의 조건부 왜도 값 $\left(\mathrm{NSKEW}_{\mathrm{t}+1}\right)$ 과 접대비(BEE_SALES)는 유의미한 양 $(+)$ 의 상관관계를, 또한 하락-상승 변동성 $\left(\mathrm{DUVOL}_{\mathrm{t}+1}\right)$ 과 접대비(BEE_SALES)는 유의미한 양(+)의 상관관계를 갖음을 확인하였다. 기업 규모(SIZE)와 주가 급락위험 $\left(\mathrm{NSKEW}_{\mathrm{t}+1}, \mathrm{DUVOL}_{\mathrm{t}+1}\right)$ 은 유의미한 양(+)의 상관관계를, 수익성 $(\mathrm{ROA})$ 과 주가 급락위험 $\left(\mathrm{NSKEW}_{\mathrm{t}+1}, \mathrm{DUVOL}_{\mathrm{t}+1}\right)$ 은 유의미한 음(-)의 상관관계를 갖는 것으로 나타났다.

\section{2 접대비 지출과 주가 급락위험}

\subsection{1 차이값 검정: 김영란법 입법 전후}

지난 2015년 김영란법의 제정 및 입법으로 기업경영의 투명성이 높아지고 부정청탁이 감소 될 것으로 기대되었고 그로 인해 기업의 접대비 지출이 매우 감소할 것으로 예측되었다. 따라서 본 절에서는 김영란법 입법 전후로 접대비 지출의 변화가 있는지 알아보기 위해 단변량 분석을 시행한다. <표 4>에는 전체표본을 김영란법 입법 전후로 구분하여 두 하위표본 간 변수들의 평균값과 중앙값의 차이를 검정한 결과가 제시되어 있다. 두 하위표본 간의 차이값 검정을 위해 평균을 이용한 $\mathrm{t}$-검정과 중앙값을 이용한 Wilcoxon 검정을 시행하였다.

가장 먼저, 주가 급락위험의 대리변수인 음 $(-)$ 의 조건부 왜도 값 $\left(\mathrm{NSKEW}_{\mathrm{t}+1}\right)$ 과 하락-상승 변동성 $\left(\mathrm{DUVOL}_{\mathrm{t}+1}\right)$ 을 살펴보면, 김영란법 도입 이전에는 각각의 평균값이 -0.4007 과 -0.2060 으로 나타났으나, 도입 이후에는 각각의 평균값이 - 0.4473 과 -0.2175 로 나타나, 주가 급락위험이 김영란법 도입 이후에 유의미하게 작아진 것을 확인할 수 있다.

다음으로 접대비 지출액(BEE)을 살펴보면, 김영란법 도입 이전에는 평균값이 347.8653이었 으나, 김영란법 도입 이후에는 평균값이 311.4642 로 나타나, 김영란법 도입 이후 접대비 지출액이 유의미하게 감소한 것을 확인할 수 있다. 접대비를 총매출액으로 나눈 값(BEE_SALES)을 보면, 김영란법 도입 이전에는 평균값이 0.0041 로, 중앙값은 0.0018 로 나타났으나, 김영란법 도입 이후에는 평균값이 0.0038 로, 중앙값은 0.0017 로 나타나, 김영란법 도입 이후 접대비를 총매출액으로 나눈 값(BEE_SALES)도 유의미하게 감소함을 확인할 수 있다. 접대비를 총자산 으로 나눈 값(BEE_ASSETSS)을 보면, 김영란법 도입 이전에는 평균값이 0.0024로, 중앙값은 0.0014 로 나타났으나, 김영란법 도입 이후에는 평균값이 0.0020으로, 중앙값은 0.0011로 나타나, 김영란법 도입 이후 접대비를 총자산으로 나눈 값(BEE_ASSETSS) 역시 유의미하게 감소함을 확인할 수 있다.

\subsection{2 접대비 지출과 주가 급락위험의 관계}

접대를 통한 관계 형성이 이해 관계자들의 신뢰를 얻고 정보의 흐름을 원활하게 한다면 주가 급락위험은 감소할 수도 있고(신뢰형성 견해), 반대로 만약 관계형성비용의 증가가 정보의 불투명 성과 경영자의 긍정적 뉴스와 부정적 뉴스의 비대칭적 처리와 관계가 있다면 주가급락 


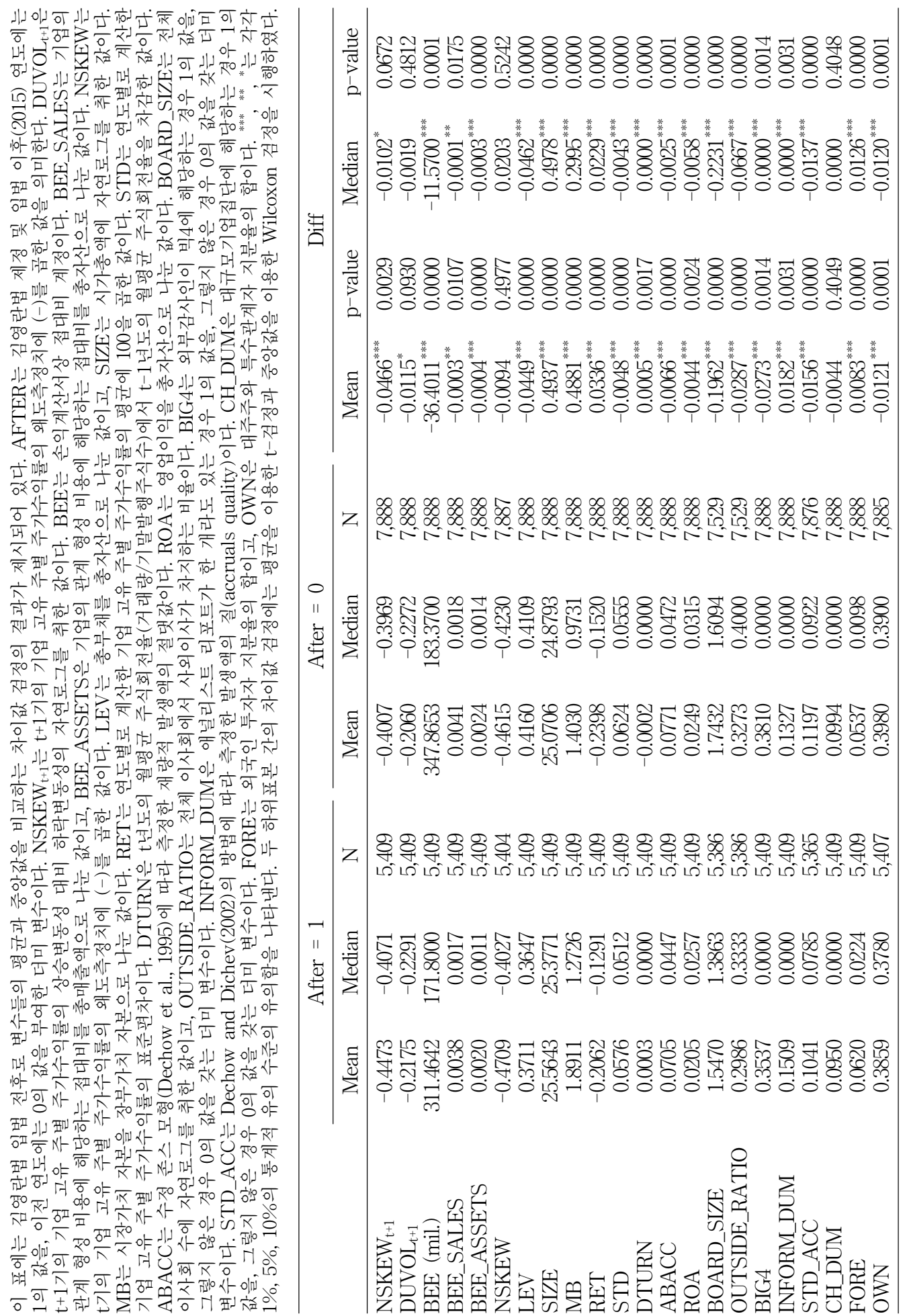


Business Entertainment Expenditure and Stock Price Crashes

〈표 5〉접대비 지출과 주가 급락위험

이 표에는 접대비 지출이 주가 급락위험에 미치는 영향의 회귀분석 결과가 제시되어 있다. $\mathrm{NSKEW}_{\mathrm{t}+1 \text { 는 }}$ $\mathrm{t}+1$ 기의 기업 고유 주별 주가수익률의 왜도측정치에 (-)를 곱한 값을 의미한다. $\mathrm{DUVOL}_{\mathrm{t}+1}$ 은 $\mathrm{t}+1$ 기의 기업 고유 주별 주가수익률의 상승변동성 대비 하락변동성의 자연로그를 취한 값이다. BEE_SALES는 기업의 관계 형성 비용에 해당하는 접대비를 총매출액으로 나눈 값이다. NSKEW는 $\mathrm{t}$ 기의 기업 고유 주별 주가수익률의 왜도측정치에 (-)를 곱한 값이다. LEV는 총부채를 총자산으로 나눈 값이고, SIZE는 시가총액에 자연로그를 취한 값이다. $\mathrm{MB}$ 는 시장가치 자본을 장부가치 자본으로 나눈 값이다. RET는 연도별로 계산한 기업 고유 주별 주가수익률의 평균에 100 을 곱한 값이다. STD는 연도별로 계산한 기업 고유 주별 주가수익률의 표준편차이다. DTURN은 t년도의 월평균 주식회전율(거래량/기말발행주식수) 에서 t-1년도의 월평균 주식회전율을 차감한 값이다. ABACC는 수정 존스 모형(Dechow et al., 1995)에 따라 측정한 재량적 발생액의 절댓값이다. $\mathrm{ROA}$ 는 영업이익을 총자산으로 나눈 값이다. $\mathrm{BOARD} S \mathrm{SIZE}$ 는 전체 이사회 수에 자연로그를 취한 값이고, OUTSIDE_RATIO는 전체 이사회에서 사외이사가 차지하는 비율이다. ${ }^{* * *},{ }^{* *},{ }^{*}$ 는 각각 $1 \%, 5 \%, 10 \%$ 의 통계적 유의 수준의 유의함을 나타낸다.

\begin{tabular}{|c|c|c|c|c|}
\hline & (1) & $(2)$ & (3) & (4) \\
\hline & $\mathrm{NSKEW}_{\mathrm{t}+1}$ & $\mathrm{NSKEW}_{\mathrm{t}+1}$ & DUVOL $_{t+1}$ & DUVOL $_{t+1}$ \\
\hline BEE_SALES & $\begin{array}{l}7.4292^{\text {*** }} \\
(3.82)\end{array}$ & $\begin{array}{c}7.5475^{\text {**** }} \\
(3.82)\end{array}$ & $\begin{array}{c}3.0546^{\text {**** }} \\
(3.57)\end{array}$ & $\begin{array}{c}2.9956^{\text {**** }} \\
(3.45)\end{array}$ \\
\hline NSKEW & $\begin{array}{c}0.0690^{\text {*** }} \\
(6.19)\end{array}$ & $\begin{array}{c}0.0652^{\text {*** }} \\
(5.82)\end{array}$ & $\begin{array}{c}0.0300^{* * *} \\
(6.23)\end{array}$ & $\begin{array}{c}0.0285^{* * *} \\
(5.92)\end{array}$ \\
\hline LEV & $\begin{array}{c}0.1518^{* * *} \\
(3.16)\end{array}$ & $\begin{array}{c}0.1388^{* * *} \\
(2.83)\end{array}$ & $\begin{array}{c}0.0678^{* * *} \\
(3.25)\end{array}$ & $\begin{array}{c}0.0590^{\text {*** }} \\
(2.77)\end{array}$ \\
\hline SIZE & $\begin{array}{l}0.1194^{\text {*** }} \\
(16.46)\end{array}$ & $\begin{array}{l}0.1227^{\text {*** }} \\
(15.85)\end{array}$ & $\begin{array}{l}0.0502^{* * *} \\
(15.51)\end{array}$ & $\begin{array}{l}0.0516^{\text {*** }} \\
(15.04)\end{array}$ \\
\hline $\mathrm{MB}$ & $\begin{array}{r}0.0073 \\
(1.00)\end{array}$ & $\begin{array}{r}0.0088 \\
(1.21)\end{array}$ & $\begin{array}{r}0.0027 \\
(0.83)\end{array}$ & $\begin{array}{r}0.0037 \\
(1.14)\end{array}$ \\
\hline RET & $\begin{array}{c}-0.5289^{* * *} \\
(-3.39)\end{array}$ & $\begin{array}{c}-0.4494^{* * *} \\
(-2.79)\end{array}$ & $\begin{array}{c}-0.3497^{* * *} \\
(-4.99)\end{array}$ & $\begin{array}{c}-0.3063^{* * *} \\
(-4.27)\end{array}$ \\
\hline STD & $\begin{array}{c}-2.5087^{* *} \\
(-2.05)\end{array}$ & $\begin{array}{r}-2.0105 \\
(-1.59)\end{array}$ & $\begin{array}{c}-2.0758^{\text {*** }} \\
(-3.80)\end{array}$ & $\begin{array}{c}-1.7934^{* * *} \\
(-3.21)\end{array}$ \\
\hline DTURN & $\begin{array}{r}0.0244 \\
(0.03)\end{array}$ & $\begin{array}{r}0.1231 \\
(0.13)\end{array}$ & $\begin{array}{r}0.0487 \\
(0.13)\end{array}$ & $\begin{array}{r}0.1162 \\
(0.30)\end{array}$ \\
\hline $\mathrm{ABACC}$ & $\begin{array}{c}0.8165^{* * *} \\
(6.73)\end{array}$ & $\begin{array}{c}0.7331^{\text {*** }} \\
(6.06)\end{array}$ & $\begin{array}{c}0.3911^{* * *} \\
(7.14)\end{array}$ & $\begin{array}{c}0.3514^{* * *} \\
(6.45)\end{array}$ \\
\hline $\mathrm{ROA}$ & $\begin{array}{c}-0.5072^{* * *} \\
(-3.90)\end{array}$ & $\begin{array}{c}-0.4657^{\text {*** }} \\
(-3.60)\end{array}$ & $\begin{array}{c}-0.2760^{\text {*** }} \\
(-4.81)\end{array}$ & $\begin{array}{c}-0.2616^{* * *} \\
(-4.53)\end{array}$ \\
\hline BOARD_SIZE & & $\begin{array}{r}0.0328 \\
(1.27)\end{array}$ & & $\begin{array}{r}0.0121 \\
(1.09)\end{array}$ \\
\hline OUTSIDE_RATIO & & $\begin{array}{c}-0.1048^{* *} \\
(-2.13)\end{array}$ & & $\begin{array}{c}-0.0414^{*} \\
(-1.92)\end{array}$ \\
\hline Intercept & $\begin{array}{l}-3.3176^{* * *} \\
(-16.97)\end{array}$ & $\begin{array}{l}-3.3350^{* * *} \\
(-16.75)\end{array}$ & $\begin{array}{l}-1.4135^{* * *} \\
(-16.21)\end{array}$ & $\begin{array}{l}-1.3967^{\text {*** }} \\
(-15.72)\end{array}$ \\
\hline Industry Dummy & Yes & Yes & Yes & Yes \\
\hline Year Dummy & Yes & Yes & Yes & Yes \\
\hline Observations & 13,291 & 12,909 & 13,291 & 12,909 \\
\hline Adjusted R-squared & 0.0519 & 0.0500 & 0.0545 & 0.0518 \\
\hline
\end{tabular}


한국증권학회지 제 50 권 1 호 (2021)

위험은 증가할 수 있다(대리인 문제 견해). 이러한 상반된 시각을 바탕으로, 본 절에서는 접대비 지출이 미래 주가 급락위험에 미치는 영향을 실증분석하고자 한다. 이에 관한 결과가 <표 $5>$ 에 제시되어 있다.

먼저 음 $(-)$ 의 조건부 왜도 값 $\left(\mathrm{NSKEW}_{\mathrm{t}+1}\right)$ 을 이용하여 분석한 모형 (1)을 살펴보면, 접대비 지출과 주가 급락위험은 유의미한 양(+)의 관계를 보이는 것으로 나타났다. 또한, 모형 (2)를 보면 기업지배구조와 관련된 통제변수인 이사회 규모(BOARD_SIZE)와 사외이사 비율 (OUTSIDE_RATIO)을 포함한 때도 여전히 접대비 지출과 주가 급락위험 간에 유의미한 양(+)의 관계가 나타났다. 다음으로, 또 다른 주가 급락위험의 대리변수인 하락-상승 변동성( $\left.\mathrm{DUVOL}_{t+1}\right)$ 을 종속변수로 사용한 모형 (3)을 보면, 접대비(BEE_SALES)의 계수값이 유의미한 양(+)의 값을 가지고 있음을 확인할 수 있다. 그리고 이사회 규모(BOARD_SIZE)와 사외이사 비율(OUTSIDE_RATIO)을 포함한 모형 (4)에서도 역시 접대비(BEE_SALES)의 계수값이 유의미한 양(+)의 값으로 나타 났다.

종합해보면, 전반적으로 모든 모형에서 접대비 지출과 주가 급락위험은 유의한 양(+)의 관계를 보이는 것으로 나타났다. 이러한 결과는 대리인 문제 가설을 지지하는 것으로 볼 수 있다. 즉, 접대비 지출을 통해 일부 이해 관계자와 관계가 너무 가까워지면 불가피하게 네트워크 외부의 주주보다 네트워크 내에서 더 많은 정보를 공유하게 되고(Granovetter, 1985; Ben et al., 2020), 정보가 비대칭인 상황에서는 정보 불투명성이 커져 내부자는 경영상의 나쁜 뉴스를 저장하는 행위를 촉진하게 될 것이기에, 결과적으로 주가 급락이 증가하게 되는 것이다.

\subsection{3 접대비 지출과 주가 급락위험의 관계: 김영란법 제정 및 입법 전후}

지난 2015년 김영란법의 제정 및 입법으로 경영 투명성이 증가하고 기업을 둘러싼 정보환경이 크게 개선될 것으로 기대되었다(Choi et al., 2019; Ben et al., 2020). 그 결과, 김영란법으로 인해 관계형성비용이 주가 급락위험에 미치는 양의 영향이 유의미하게 감소할 것으로 예상된다 (Ben et al., 2020). 따라서 본 연구에서는 김영란법의 도입이 접대비 지출과 주가 급락위험 간의 관계에 어떠한 영향을 미치는지 살펴보고자 한다. 이를 위하여 접대비(BEE_SALES)와 김영란법의 도입 이후를 의미하는 더미 변수(AFTER)의 교차항인 BEE_SALES $\times$ AFTER를 회귀모형에 포함하여 DID(Difference in Difference) 분석을 진행하였다.

<표 6>에 제시된 결과 중 모형 (1)과 (2)는 음의 조건부 왜도(NSKEW)를 종속변수로 하여 분석한 결과이며, (3)과 (4)는 하락-상승 변동성(DUVOL)을 종속변수로 설정하여 분석한 결과이다. 두 변수를 이용한 분석은 상당히 유사한 결과를 보였다. 두 경우 모두 앞선<표 $5>$ 의 결과와 동일하게 주가 급락위험에 대한 접대비(BEE_SALES)의 계수가 양의 값을 보였으며 통계적 유의성도 높게 나타났다. 이러한 결과는 기업지배구조와 관련된 통제변수인 이사회 규모(BOARD_SIZE)와 사외이사 비율(OUTSIDE_RATIO)을 포함한 모형 (2)와 (4)에서도 동일하게 나타났다.

또한, BEE_SALES $\times$ AFTER의 계수값을 살펴보면, 모든 모형에서 유의미한 음의 값을 갖고 있음을 확인할 수 있다. 이러한 결과는 김영란법 도입 이후 접대비가 주가 급락위험에 미치는 영향이 매우 유의하게 감소하였음을 보여준다. 이와 더불어, BEE_SALES의 계수값과 BEE_ 
Business Entertainment Expenditure and Stock Price Crashes

〈표 6〉접대비 지출과 주가 급락위험: 김영란법 제정 및 입법 전후

이 표에는 김영란법 제정 및 입법 이후 접대비 지출이 주가 급락위험에 미치는 영향의 회귀분석 결과가 제시되어 있다. $\mathrm{NSKEW}_{\mathrm{t}+1}$ 는 $\mathrm{t}+1$ 기의 기업 고유 주별 주가수익률의 왜도측정치에 (-)를 곱한 값을 의미한다. $\mathrm{DUVOL}_{\mathrm{t}+1}$ 은 $\mathrm{t}+1$ 기의 기업 고유 주별 주가수익률의 상승변동성 대비 하락변동성의 자연로그를 취한 값이다. BEE_SALES는 기업의 관계 형성 비용에 해당하는 접대비를 총매출액으로 나눈 값이다. AFTER는 김영란법 제정 및 입법 이후(2015) 연도에는 1 의 값을, 이전 연도에는 0 의 값을 부여한 더미 변수이다. NSKEW는 $\mathrm{t}$ 기의 기업 고유 주별 주가수익률의 왜도측정치에 (-)를 곱한 값이다. LEV는 총부채를 총자산으로 나눈 값이고, $\mathrm{SIZE}$ 는 시가총액에 자연로그를 취한 값이다. $\mathrm{MB}$ 는 시장가치 자본을 장부가치 자본으로 나눈 값이다. RET는 연도별로 계산한 기업 고유 주별 주가수익률의 평균에 100 을 곱한 값이다. STD는 연도별로 계산한 기업 고유 주별 주가수익률의 표준편차이다. DTURN은 $\mathrm{t}$ 년도의 월평균주식회전율(거래량/기말 발행주식수)에서 t-1년도의 월평균 주식회전율을 차감한 값이다. ABACC는 수정 존스 모형(Dechow et al., 1995)에 따라 측정한 재량적 발생액의 절댓값이다. ROA는 영업이익을 총자산으로 나눈 값이다. BOARD_SIZE는 전체 이사회 수에 자연로그를 취한 값이고, OUTSIDE_RATIO는 전체 이사회에서 사외이사가 차지하는 비율이다. ${ }^{* * *},{ }^{* *}$, ${ }^{*}$ 는 각각 $1 \%, 5 \%, 10 \%$ 의 통계적 유의 수준의 유의함을 나타낸다.

\begin{tabular}{|c|c|c|c|c|}
\hline & (1) & (2) & (3) & (4) \\
\hline & NSKEW $_{\mathrm{t}+1}$ & NSKEW $_{\mathrm{t}+1}$ & DUVOL $_{t+1}$ & DUVOL $_{t+1}$ \\
\hline BEE_SALES $\left(\beta_{1}\right)$ & $\begin{array}{c}10.0415^{* * * *} \\
(4.42)\end{array}$ & $\begin{array}{c}10.3213^{* * * *} \\
(4.37)\end{array}$ & $\begin{array}{l}4.1727^{* * *} \\
(3.99)\end{array}$ & $\begin{array}{l}4.1297^{* * *} \\
(3.82)\end{array}$ \\
\hline BEE_SALES & $-6.8348^{* *}$ & $-6.9780^{* *}$ & $\begin{array}{l}-2.9253^{* *} \\
(-212)\end{array}$ & $\begin{array}{l}-2.8532^{* *} \\
(-201)\end{array}$ \\
\hline AFTER & $\begin{array}{l}-0.0749^{* *} \\
(-2.06)\end{array}$ & $\begin{array}{r}-0.0481 \\
(-1.24)\end{array}$ & $\begin{array}{r}-0.0191 \\
(-1.23)\end{array}$ & $\begin{array}{r}-0.0108 \\
(-0.65)\end{array}$ \\
\hline NSKEW & $\begin{array}{l}0.0685^{* * *} \\
(6.14)\end{array}$ & $\begin{array}{l}0.0647^{* * *} \\
(5.77)\end{array}$ & $\begin{array}{l}0.0298^{* * * *} \\
(6.19)\end{array}$ & $\begin{array}{l}0.0283^{* * *} \\
(5.88)\end{array}$ \\
\hline LEV & $\begin{array}{l}0.1519^{* * *} \\
(3.17)\end{array}$ & $\begin{array}{l}0.1383^{* * *} \\
(2.82)\end{array}$ & $\begin{array}{l}0.0679^{* * * *} \\
(3.25)\end{array}$ & $\begin{array}{l}0.0589^{* * * *} \\
(2.77)\end{array}$ \\
\hline SIZE & $\begin{array}{l}0.1196^{* * *} \\
(16.50)\end{array}$ & $\begin{array}{l}0.1225^{* * *} \\
(15.83)\end{array}$ & $\begin{array}{l}0.0502^{* * *} \\
(15.54)\end{array}$ & $\begin{array}{l}0.0515^{* * *} \\
(15.03)\end{array}$ \\
\hline $\mathrm{MB}$ & $\begin{array}{r}0.0086 \\
(1.16)\end{array}$ & $\begin{array}{r}0.0101 \\
(1.38)\end{array}$ & $\begin{array}{r}0.0032 \\
(0.99)\end{array}$ & $\begin{array}{r}0.0042 \\
(1.29)\end{array}$ \\
\hline RET & $\begin{array}{l}-0.5122^{* * *} \\
(-3.29)\end{array}$ & $\begin{array}{l}-0.4324^{* * *} \\
(-2.69)\end{array}$ & $\begin{array}{l}-0.3425^{* * *} \\
(-4.90)\end{array}$ & $\begin{array}{l}-0.2994^{\text {**** }} \\
(-4.18)\end{array}$ \\
\hline STD & $\begin{array}{l}-2.4196^{* *} \\
(-1.98)\end{array}$ & $\begin{array}{r}-1.9217 \\
(-1.53)\end{array}$ & $\begin{array}{l}-2.0376^{* * *} \\
(-3.74)\end{array}$ & $\begin{array}{l}-1.7571^{* * *} \\
(-3.15)\end{array}$ \\
\hline DTURN & $\begin{array}{r}0.0431 \\
(0.05)\end{array}$ & $\begin{array}{r}0.1373 \\
(0.15)\end{array}$ & $\begin{array}{r}0.0567 \\
(0.15)\end{array}$ & $\begin{array}{r}0.1220 \\
(0.32)\end{array}$ \\
\hline $\mathrm{ABACC}$ & $\begin{array}{l}0.8136^{* * *} \\
(6.71)\end{array}$ & $\begin{array}{l}0.7307^{* * *} \\
(6.05)\end{array}$ & $\begin{array}{l}0.3899^{* * *} \\
(7.13)\end{array}$ & $\begin{array}{l}0.3504^{* * *} \\
(6.45)\end{array}$ \\
\hline $\mathrm{ROA}$ & $\begin{array}{l}-0.5055^{\text {*** }} \\
(-3.89)\end{array}$ & $\begin{array}{l}-0.4632^{* * *} \\
(-3.58)\end{array}$ & $\begin{array}{l}-0.2753^{* * * *} \\
(-4.80)\end{array}$ & $\begin{array}{l}-0.2606^{* * *} \\
(-4.51)\end{array}$ \\
\hline BOARD_SIZE & & $\begin{array}{r}0.0361 \\
(1.40)\end{array}$ & & $\begin{array}{r}0.0135 \\
(1.21)\end{array}$ \\
\hline OUTSIDE_RATIO & & $\begin{array}{l}-0.1023^{* *} \\
(-2.08)\end{array}$ & & $\begin{array}{l}-0.0404^{*} \\
(-1.88)\end{array}$ \\
\hline Intercept & $\begin{array}{l}-3.3345^{* * *} \\
(-17.09)\end{array}$ & $\begin{array}{l}-3.3465^{* * *} \\
(-16.90)\end{array}$ & $\begin{array}{l}-1.4207^{* * *} \\
(-16.31)\end{array}$ & $\begin{array}{l}-1.4014^{* * *} \\
(-15.86)\end{array}$ \\
\hline Industry Dummy & Yes & Yes & Yes & Yes \\
\hline Year Dummy & Yes & Yes & Yes & Yes \\
\hline$\beta_{1}+\beta_{2}$ & 3.2067 & 3.3433 & 1.2474 & 1.2765 \\
\hline p_value & 0.2385 & 0.2191 & 0.2801 & 0.2703 \\
\hline Observations & 13,291 & 12,909 & 13,291 & 12,909 \\
\hline Adjusted R-squared & 0.0523 & 0.0505 & 0.0549 & 0.0522 \\
\hline
\end{tabular}


한국증권학회지 제 50 권 1 호 (2021)

SALES $\times$ AFTER의 계수값의 결합 유의성(joint significance)을 살펴보기 위해 wald test를 실시해본 결과, BEE_SALES의 계수값과 $\mathrm{BEE} \_\mathrm{SALES} \times \mathrm{AFTER}$ 의 계수값의 합은 더는 유의하지 않은 양 $(+)$ 의 값을 갖는 것을 확인할 수 있다. 즉, 접대비(BEE_SALES)의 계수값은 매우 유의미한 양의 값을 가져 김영란법 도입 이전에는 접대비 지출이 주가 급락위험에 매우 유의미한 양 $(+)$ 의 영향을 미쳤으나, BEE_SALES의 계수값과 BEE_SALES $\times$ AFTER의 계수값의 합은 더이상 유의미하지 않아 김영란법 도입 이후에는 이러한 양 $(+)$ 의 영향이 감소하는 것으로 나타났다. 또한, 이사회 규모(BOARD_SIZE)와 사외이사 비율(OUTSIDE_RATIO)을 포함한 모형에서도 유사한 결과가 나타났다. 본 연구의 결과는 김영란법의 입법 이후 기업의 접대비 지출이 주가 급락위험에 미치는 양의 영향이 크게 완화함을 보임으로써 부정부패를 근절하고자 하는 정책이 기업의 정보환경을 크게 개선시키고 대리인 문제를 완화하였다는 근거를 제시하고 있다.

\subsection{4 접대비 지출과 주가 급락위험의 관계: 정보 불투명성으로 구분}

기존 문헌에 따르면, 주가 급락위험은 재무적·회계적 투명성 및 부정적인 정보의 흐름과 같이 기업을 둘러싼 정보환경과 연관되어 있다(Hutton et al., 2009; Kim and Zhang., 2014; Kim et al., 2011b; Ben et al., 2020). 특히 이러한 기존 연구에 따르면, 기업의 정보 불투명성은 주가 급락위험을 증가시키는 것으로 나타났다. 정보 불투명성이 높을수록 경영상의 나쁜 뉴스를 저장하는 행위를 촉진하게 될 것이기 때문이다. 이와 같은 논의를 바탕으로 본 논문에서는 정보의 불투명성이 높고 낮은 경우 접대비 지출이 각각 주가 급락위험에 어떠한 영향을 미치는지 연구하고자 한다. 이를 위해서 정보 불투명성의 수준에 따라 하위표본으로 나눈 후 앞선 회귀분석과 동일한 분석을 진행하였다. 만약 접대비 지출과 주가 급락위험의 양의 상관관계가 정보의 비대칭과 나쁜 뉴스의 축적에 따른 결과라면, 정보 불투명성의 정도는 둘 간의 관계에 영향을 미칠 수 있다. 따라서 기업의 정보 불투명성이 높을수록 접대비 지출과 주가 급락의 유의미한 양의 관계가 더욱 강하게 나타날 것으로 예상하는 반면, 정보 불투명성이 낮을수록 접대비 지출과 주가 급락위험의 양의 관계는 나타나지 않으리라고 예상한다. 아울러, 기업을 둘러싼 정보환경이 이미 투명하다면 부정부패 방지를 위한 김영란법의 효과 역시 미미할 것으로 예상한다.

기존 연구에 따라, 정보의 불투명성을 나타내는 대리변수로 발생액의 질(accrual quality)과 대형 외부감사인 여부(Big4)를 사용하고자 한다(Kim and Zhang, 2014; Firth et al., 2015; DeFond et al., 1999; Dechow and Dichev, 2002; Ben et al., 2020). 많은 연구에서는 기업의 회계 투명성을 측정하는 수단으로 발생액의 질(accrual quality)을 사용한다(Dechow and Dichev, 2002; Kim and Zhang, 2014; Ben et al., 2020). 먼저, 발생액의 질은 Dechow and Dichev(2002)의 모형에 따라 추정된 잔차의 표준편차로 측정하며, 이 값이 클수록 발생액의 질은 낮아지고 정보 불투명성이 증가하는 것으로 해석한다. 또한, 기존연구에 따라 대형 외부감사인(Big4) 여부를 정보 투명성의 대용치로 사용하고자 한다(DeFond et al., 1999; Firth et al., 2015; Ben et al., 2020). Big4 회계법인은 국내 감사 시장에서 대형 회계법인으로서 지켜온 전문가적 평판(reputation)을 유지하고자 할 것이고, 만에 하나 있을 큰 손실을 초래하는 
소송에 처할 위험을 피하고자 노력할 것이다. 그러므로 $\operatorname{Big} 4$ 회계법인은 높은 품질의 감사 서비스를 제공하고자 할 것이고 이들의 외부감사는 기업의 회계적 투명성을 제고할 것이다.

<표 7>의 Panel A에는 발생액의 질을 기준으로 구분하여 분석한 결과가 제시되어 있다. 모형 (1) (4)에는 Dechow and Dichev(2002)의 모형에 따라 추정된 잔차의 표준편차가 큰 경우, 즉 발생액의 질이 낮고 정보의 불투명성이 높은 기업을 대상으로 분석한 결과가 제시되어있고, 모형 (5) (8)에는 발생액의 질이 높고 정보의 불투명성이 낮은 기업에 대한 분석결과가 제시되어 있다. 먼저, 발생액의 질이 낮은 기업을 대상으로 한 분석결과를 살펴보면, 모든 모형에서 접대비(BEE_SALES)의 계수값이 유의미한 양(+)의 값을 가지고 있어 여전히 대리인 문제 가설을 지지함을 확인할 수 있다. 정보 불투명성이 높은 경우, 접대비 지출을 통해 네트워크 내부자와 외부자 사이에 정보 비대칭성과 불투명성이 증가하게 되고, 경영자의 나쁜 정보를 축적하려는 경향이 증가 될 것이므로 주가 급락위험이 증가하게 되는 것이다. 또한, 김영란법의 입법 이후 접대비 지출이 주가 급락위험에 미치는 영향을 살펴보기 위해 교차항인 BEE_SALES $\times A F T E R$ 를 포함한 모형 (2)와 (4)를 살펴보면, 정보 불투명성이 높은 경우 $\mathrm{BEE} \_\mathrm{SALES} \times \mathrm{AFTER}$ 의 계수값이 유의미한 음의 값을 가지고 있어, 김영란법의 입법이 접대비와 주가 급락위험 간의 유의미한 양의 관계를 크게 완화하고 있음을 보여준다. 계수값의 결합 유의성(joint significance)을 보여주는 wald test의 결과에서도 BEE_SALES의 계수값과 $\mathrm{BEE} \_\mathrm{SALES} \times \mathrm{AFTER}$ 의 계수값의 합은 유의하지 않은 양(+)의 값을 갖는 것을 확인할 수 있다. 즉, 김영란법의 제정 및 입법으로 기업의 경영 투명성이 증가하였음을 보여주는 결과이다. 한편, 발생액의 질이 높은 기업을 대상으로 분석한 결과를 살펴보면, 접대비(BEE_SALES)의 계수값은 통계적 유의성이 없는 것으로 나타나, 정보의 불투명성이 낮은 경우에는 접대비 지출이 주가 급락위험에 미치는 영향이 미미한 것으로 확인되었다. 또한, 교차항이 포함된 모형 (6)과 (8)에서도 BEE_SALES $\times$ AFTER의 계수값의 유의성이 없는 것으로 확인되었다.

$<$ 표 7>의 Panel B에는 전체표본을 대형 외부감사인(Big4) 선임 여부를 기준으로 나누어 분석한 결과가 제시되어 있다. 먼저, 외부감사인이 대형 회계법인에 속하지 않는 기업을 대상으로 한 분석결과를 살펴보면, 모형 (1)-(4)에서 접대비(BEE_SALES) 계수의 t-값이 대략 3.00보다 크거나 작은 정도로 나타나 매우 유의미한 양 $(+)$ 의 값을 가지고 있음을 확인할 수 있었다. 반면에 외부감사인이 대형 회계법인에 속한 기업의 경우에는 음(-)의 조건부 왜도 값 $\left(\mathrm{NSKEW}_{\mathrm{t}+1}\right)$ 을 종속변수로 한 모형 (5)와 (6)에서는 접대비(BEE_SALES) 계수의 $\mathrm{t}$-값이 각각 1.68과 1.76으로 나타나 유의성이 상대적으로 낮게 나타났고, 하락-상승 변동성 $\left(\mathrm{DUVOL}_{\mathrm{t}+1}\right)$ 을 종속변수로 한 모형 (7)과 (8)을 보면 아예 통계적 유의성이 없는 것으로 나타났다. 즉, 대형 외부감사인을 선임하지 않은 기업, 다시 말해 정보 불투명성이 높은 기업의 경우 접대비와 주가 급락위험의 양의 관계가 더 유의미하게 나타났다. 한편 모형 (2)와 (4)를 보면, 교차항인 BEE_SALES× AFTER를 포함한 모형에서 교차항의 계수값은 유의미한 음의 값을 갖진 않았지만, 계수값의 결합 유의성(joint significance)을 보여주는 wald test의 결과에서는 유의했던 BEE_SALES의 계수값이 BEE_SALES $\times$ AFTER의 계수값과 더하자 더이상 유의하지 않은 것으로 나타나, 여전히 김영란법의 입법이 접대비와 주가 급락위험간의 유의미한 양의 관계를 완화하고 있음을 보여준다. 


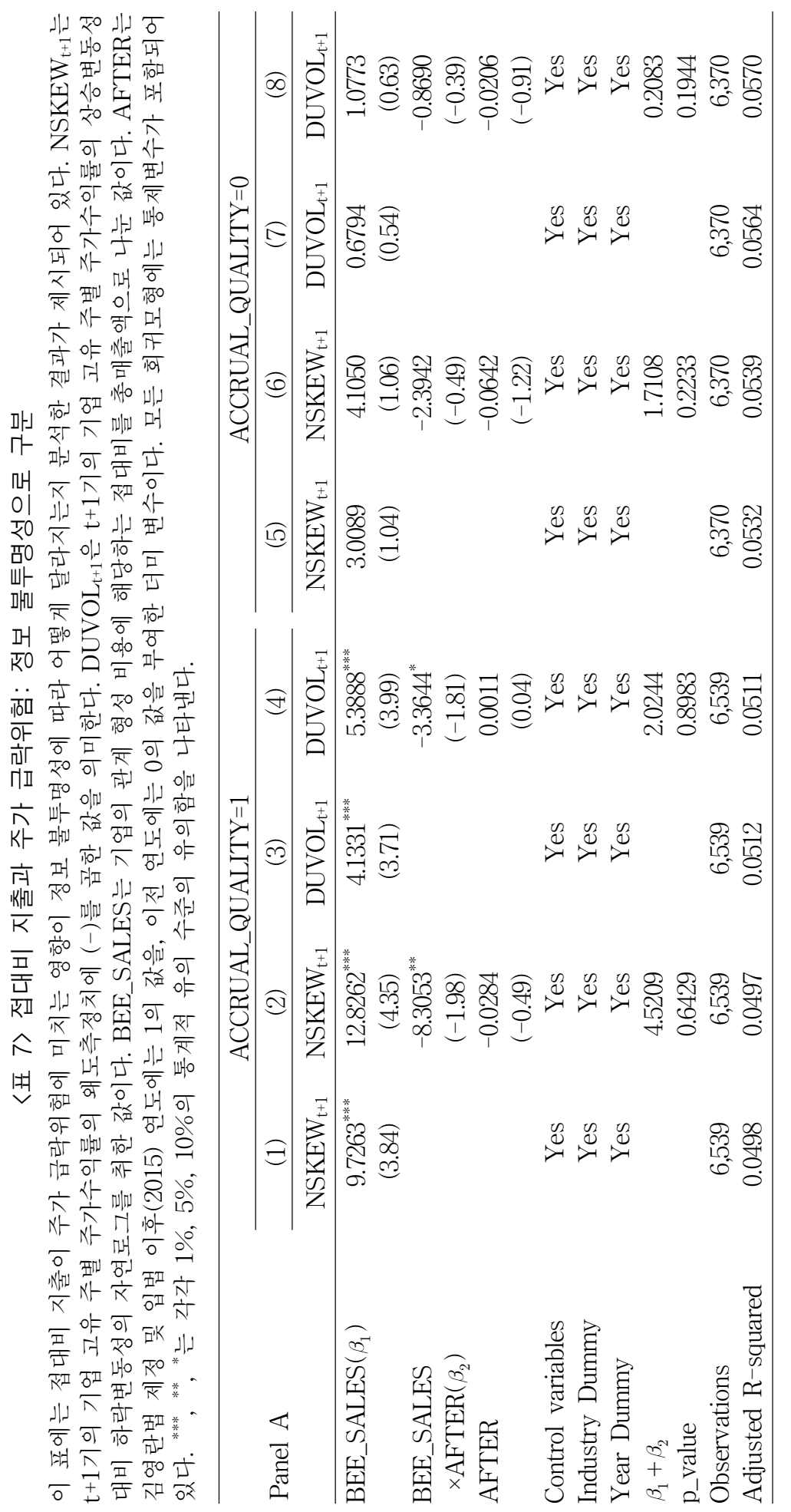


Business Entertainment Expenditure and Stock Price Crashes

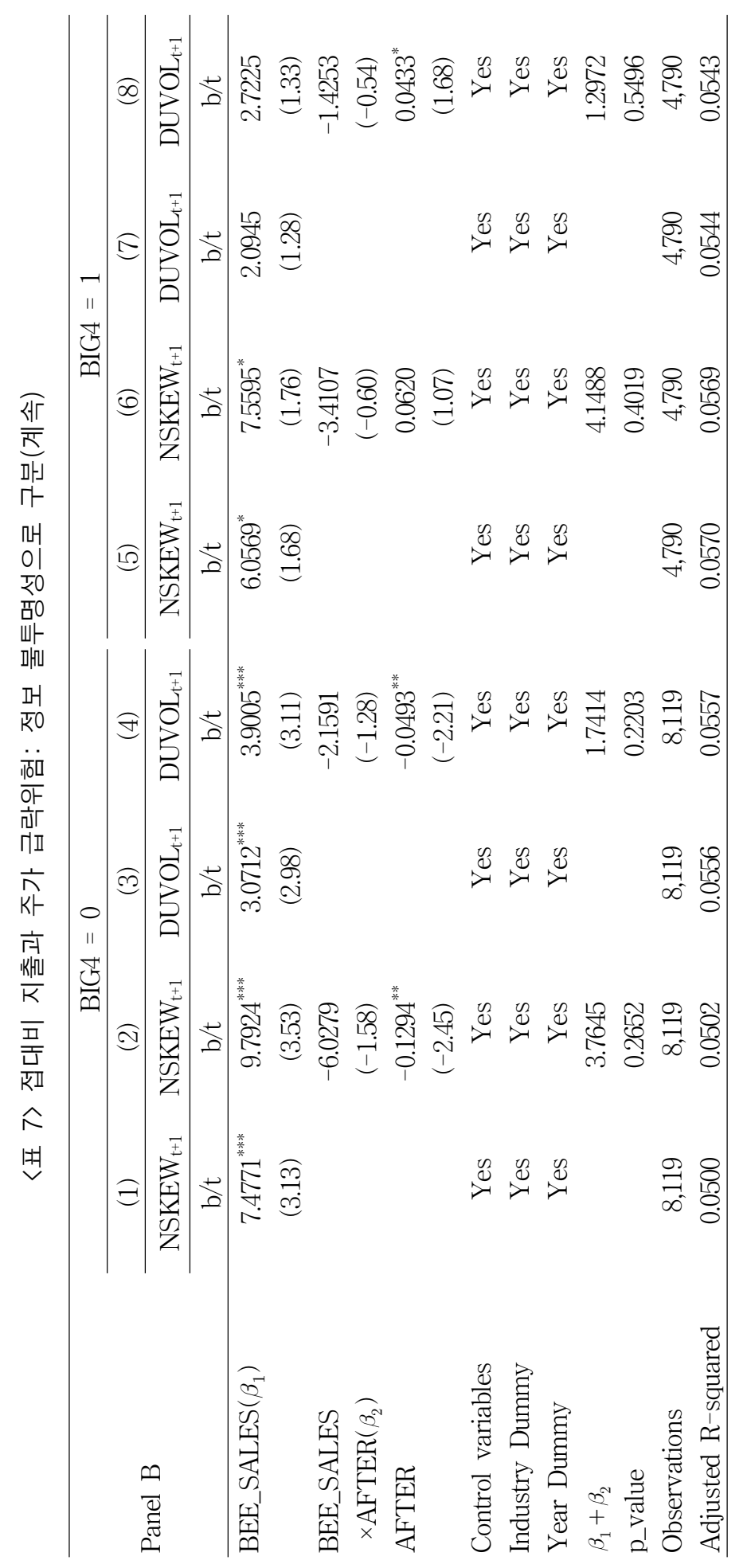


한국증권학회지 제 50 권 1 호 (2021)

분석결과를 정리하면, 정보 불투명성이 높은 기업은 접대비 지출이 증가할 때 주가 급락위험이 매우 유의미하게 증가하는 반면, 정보 불투명성이 낮은 기업은 접대비 지출과 주가 급락위험간에 유의미한 상관관계가 존재하지 않음을 확인할 수 있다. 이러한 결과는 정보 불투명성이 주가 급락위험을 증가시킨다는 기존 연구의 결과와 부합하는 결과이다(Hutton et al., 2009; Kim and Zhang, 2014; Kim et al., 2011b; Ben et al., 2020). 또한 김영란법과 같이 부정부패를 방지하고자 하는 정책은 기업의 정보환경이 좋지 않았을 때 정보 투명성을 더 크게 개선시킴을 확인할 수 있다.

\section{3 접대비 지출 공시기업 vs. 비공시기업}

우리나라에서 손익계산서상 접대비 계정은 의무공시 항목이 아니기에 접대비 계정의 세부금액을 분리 공시하지 않고 전체 판매관리비로 묶어서 공시할 수 있다. 다시 말해, 접대비 분리공시가 선택적으로 이루어질 수 있는 것이다. 내부자는 재량적 비용이자 따로 공시하지 않아도 되는 접대비를 통해 더욱 쉽게 기업의 자원을 유용하여 사익편취를 할 수 있다. 그 결과, 접대비를 따로 공시하지 않는 기업의 경우 상대적으로 소유구조가 나쁘고, 대리인 비용이 크며, 기업지배구조가 나쁠 것으로 기대된다. 따라서 본 절에서는 소유구조, 대리인 비용, 그리고 기업지배구조의 대리변수를 이용하여 국내 기업들의 접대비 분리공시의 결정요인을 살펴보고자 한다. 이때, 소유구조 변수로는 재벌 더미(CH_DUM), 대주주와 특수관계자 지분율의 합(OWN), 그리고 외국인 지분율(FORE)을 사용한다. 대리인 비용 변수로는 Ang et al.(2000)과 Singh and Davidson(2003)에서 사용한 판매관리비 비율(SG\&A_SALES)과 자산회전율(SALES_ $\mathrm{ASSET})$ 을 사용한다. 먼저, 판매관리비 비율을 살펴보면, 영업과 관련된 판매관리비에는 내부자의 재량으로 결정될 수 있는 부분이 많으므로 판매관리비 비율을 통해 사적 소비를 포함한 판매관리비를 내부자가 얼마나 효율적으로 통제하고 있는지 볼 수 있다. 따라서 매출액 대비 판매관리비가 클수록 대리인 비용은 커진다고 본다. 자산회전율의 경우, 기업의 자산을 비효율적 으로 사용함에 따라 발생하는 수익의 감소를 측정하는 변수로, 기존 연구에서는 이 비율이 낮을수록 대리인 비용은 커진다고 본다. 마지막으로, 기업지배구조 대리변수인 이사회 규모 (BOARD_SIZE)와 사외이사 비율(OUTSIDE_RATIO)을 포함한다(Ben et al., 2020).

\subsection{1 차이값 검정: 접대비 지출 공시기업과 비공시기업}

본 절에서는 전체표본을 접대비 계정을 분리 공시하는 기업과 그렇지 않은 기업으로 나누어, 접대비 분리공시의 결정요인 변수와 기업특성 변수의 유의미한 차이가 있는지 확인하고자 한다. 이를 위해, 평균을 이용한 $\mathrm{t}$-검정과 중앙값을 이용한 Wilcoxon 검정을 시행하였다.

$<$ 표 8>에는 두 하위표본 간 변수들의 평균값과 중앙값의 차이를 검정한 결과가 제시되어 있다. 먼저 주가 급락위험의 대리변수인 음 $(-)$ 의 조건부 왜도 값 $\left(\mathrm{NSKEW}_{\mathrm{t}+1}\right)$ 과 하락-상승 변동성 $\left(\mathrm{DUVOL}_{\mathrm{t}+1}\right)$ 을 살펴보면, 접대비 분리공시를 하는 경우 각각의 평균값이 -0.4200 과 -0.2110 으로 나타났으나, 분리공시를 하지 않는 경우 각각의 평균값은 -0.3080 과 -0.1580 으로 나타나, 주가 급락위험이 분리공시를 하지 않을 때 더 유의미하게 커진 것을 확인할 수 있다. 내부자는 접대비를 통한 자신의 사익추구와 향락적 소비를 은닉하고자 할 때 분리공시를 하지 
Business Entertainment Expenditure and Stock Price Crashes

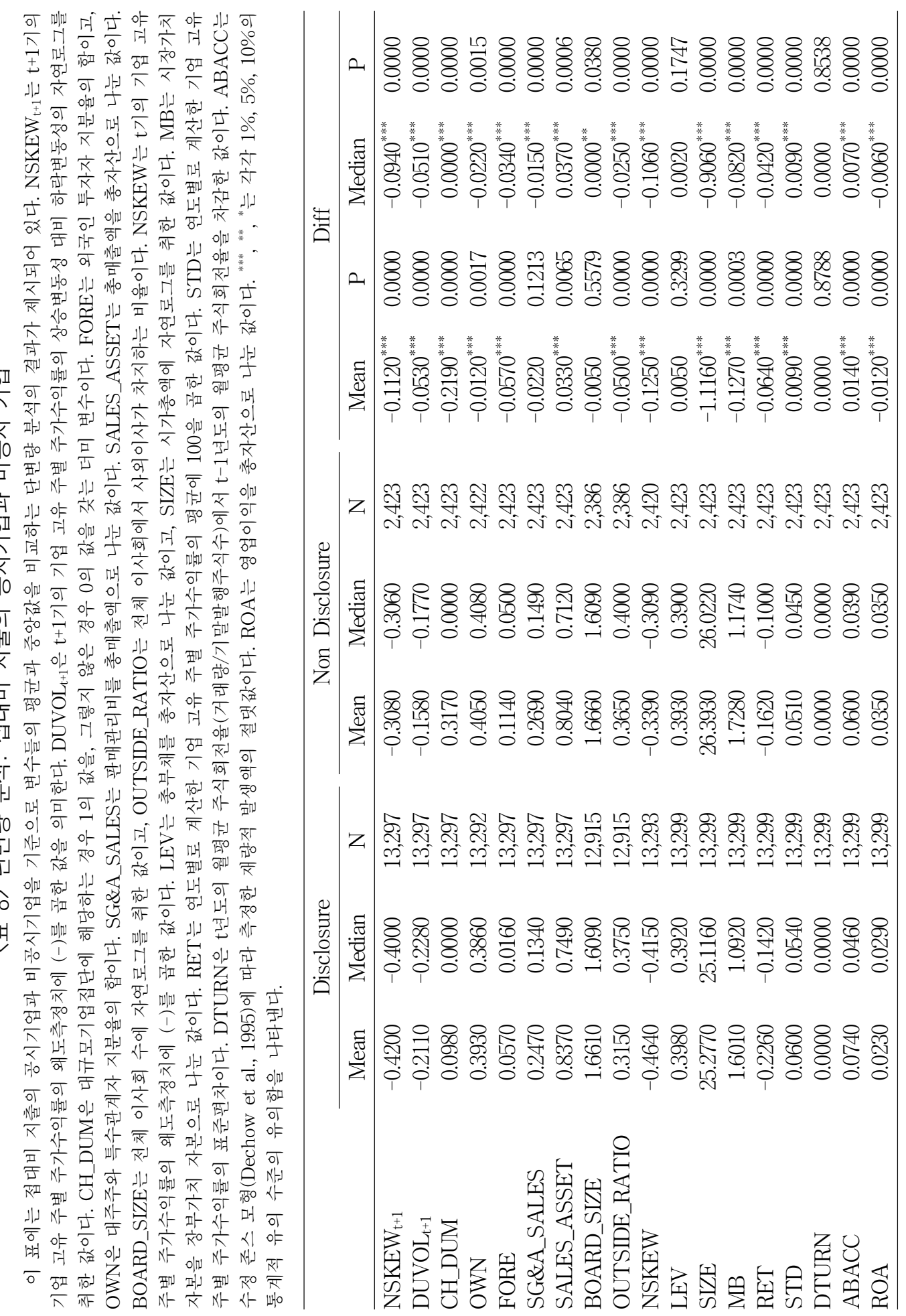


한국증권학회지 제 50 권 1호 (2021)

않을 것이고, 이런 경우 내부자와 외부자 사이에 정보 비대칭성과 불투명성이 증가하게 될 것이며, 결과적으로 주가 급락이 증가하게 되는 것이다.

기업지배구조의 대리변수인 재벌 더미(CH_DUM)를 살펴보면, 접대비를 공시하는 경우 재벌 더미(CH_DUM)의 평균값이 0.0980 으로 나타났으나, 접대비를 공시하지 않는 기업은 0.3170으로 나타나, 접대비를 공시하지 않는 기업이 대규모기업집단에 더 많이 해당하는 것으로 나타났다. 즉, 재벌에 해당하는 기업일수록 접대비를 따로 분리공시 하지 않는 것으로 확인되었다. 대주주와 특수관계자 지분율의 합 $(\mathrm{OWN})$ 을 보면, 접대비를 분리공시 하지 않는 기업의 지분율 평균은 0.4050 , 중앙값은 0.4080 으로 나타났지만, 공시하는 기업의 경우 각각 0.3930 과 0.3860 으로 나타났다. 즉, 접대비를 공시하지 않는 기업의 경우 대주주 지분율이 더 유의적으로 높게 나타나, 집중된 소유구조를 보일 때 접대비 분리공시에 더욱 소극적임을 확인하였다. 또한, 외국인 지분율(FORE)을 살펴보면, 접대비를 분리공시 하지 않는 기업의 외국인 지분율이 유의하게 높은 것으로 확인되었는데, 이러한 결과는 외국인 투자자가 많은 경우 재량적 비용이자 자원유용에 용이한 접대비의 세부 금액을 감추고자 하여 오히려 분리 공시하지 않는 것으로 볼 수 있다.

다음으로 대리인 비용의 대리변수인 판매관리비 비율(SG\&A_SALES)의 경우, 분리공시를 하는 경우보다 분리공시를 하지 않는 경우의 평균값과 중앙값이 모두 더 크게 나타나, 분리공시를 하지 않는 경우 대리인 비용이 더 큰 것으로 나타났다. 또한, 대리인 비용과 역의 관계를 갖는 자산회전율(SALES_ASSET)의 경우, 분리공시를 하지 않는 경우의 평균값과 중앙값이 모두 더 작게 나타나, 이 경우에도 분리공시를 하지 않는 경우 대리인 비용이 더 큰 것으로 나타났다. 마지막으로, 기업지배구조의 대리변수인 이사회 규모(BOARD_SIZE)와 사외이사 비율 (OUTSIDE_RATIO)을 살펴보면, 두 변수 모두 접대비를 분리 공시하지 않는 기업의 경우 더 크게 나타났다. 이와 함께 기업 규모를 살펴보면, 접대비를 분리 공시하지 않는 기업의 기업 규모가 매우 유의하게 더 크게 나타났다. 이사회 규모와 사외이사 비율의 경우 기업규모의 영향을 크게 받으므로, 이사회 규모와 사외이사 비율이 접대비를 분리 공시하지 않는 경우에 더 크게 나타난 것으로 판단된다.

\subsection{2 접대비 공시의 결정요인}

앞선 분석에서 접대비와 주가 급락위험의 양의 관계를 밝혀냈고, 이는 결국 대리인 문제 가설을 지지하는 결과임을 확인하였다. 즉, 접대비 지출은 내부자의 재량적 소비이자 사적 소비를 의미한다고 볼 수 있다. 이는 기업 내 자원의 유용을 쉽게 하는 수단이 되는 것이다. 여기서 한 가지 흥미로운 점은 접대비 공시는 기업의 재량적 의사결정이기에 내부자가 임의로 공시 여부를 선택할 수 있다. 따라서 기업의 내부자 관점에서 접대비를 통한 자신의 사익추구 행위가 잘 드러날 염려가 있을 때 이들은 접대비 분리공시에 소극적일 것이다.

본 절에서는 과연 어떤 기업이 접대비 분리공시를 하는지 확인하고자 접대비 공시의 결정요인을 살펴보고자 한다. 이를 위해 접대비 분리공시를 하는 경우 1 의 값을, 그렇지 않은 경우 0 의 값을 부여한 더미 변수를 종속변수로 사용하여 로짓 회귀분석을 시행한다. 이때 접대비 공시에 영향을 미칠 수 있는 요인인 소유구조, 대리인 비용, 그리고 기업지배구조 대리변수를 이용한다. 
Business Entertainment Expenditure and Stock Price Crashes

〈표 9〉 접대비 공시의 결정요인

이 표에는 접대비 공시의 결정요인을 알아보기 위한 로짓 회귀분석의 결과가 제시되어 있다. Disclosuret+1는 손익계산서에 접대비 계정을 따로 분리공시하는 기업의 경우 1 의 값을, 그렇지 않은 경우 0 의 값을 갖는 더미 변수이다. CH_DUM은 대규모기업집단에 해당하는 경우 1 의 값을, 그렇지 않은 경우 0 의 값을 갖는 더미 변수이다. FORE는 외국인 투자자 지분율의 합이고, OWN은 대주주와 특수관계자 지분율의 합이다. SG\&A_SALES는 판매관리비를 총매출액으로 나눈 값이다. SALES_ASSET는 총매출액을 총자산으로 나눈 값이다. BOARD_SIZE는 전체 이사회 수에 자연로그를 취한 값이고, OUTSIDE_RATIO는 전체 이사회에서 사외이사가 차지하는 비율이다. NSKEW는 $\mathrm{t}$ 기의 기업 고유 주별 주가수익률의 왜도측정치에 (-)를 곱한 값이다. $\mathrm{LEV}$ 는 총부채를 총자산으로 나눈 값이고, $\mathrm{SIZE}$ 는 시가총액에 자연로그를 취한 값이다. $\mathrm{MB}$ 는 시장가치 자본을 장부가치 자본으로 나눈 값이다. RET는 연도별로 계산한 기업 고유 주별 주가수익률의 평균에 100 을 곱한 값이다. STD는 연도별로 계산한 기업 고유 주별 주가수익률의 표준편차이다. DTURN은 t년도의 월평균 주식회전율(거래량/기말발행주식수)에서 $\mathrm{t}-1$ 년도의 월평균 주식회전율을 차감한 값이다. ABACC는 수정 존스 모형(Dechow et al., 1995)에 따라 측정한 재량적 발생액의 절댓값이다. $\mathrm{ROA}$ 는 영업이익을 총자산으로 나눈 값이다. ${ }^{* * *},{ }^{* *},{ }^{*}$ 는 각각 $1 \%, 5 \%, 10 \%$ 의 통계적 유의 수준의 유의함을 나타낸다.

\begin{tabular}{|c|c|c|c|c|}
\hline & (1) & (2) & (3) & (4) \\
\hline & Disclosuret+1 & Disclosuret +1 & Disclosuret +1 & Disclosuret +1 \\
\hline \multicolumn{5}{|l|}{ Ownership structure } \\
\hline CH_DUM & & $\begin{array}{c}-0.6208^{* * *} \\
(-8.03)\end{array}$ & $\begin{array}{c}-0.6612^{* * *} \\
(-8.62)\end{array}$ & $\begin{array}{l}-0.6404^{* * *} \\
(-8.24)\end{array}$ \\
\hline OWN & & $\begin{array}{r}0.0018 \\
(0.01)\end{array}$ & $\begin{array}{r}-0.0317 \\
(-0.23)\end{array}$ & $\begin{array}{r}-0.0167 \\
(-0.12)\end{array}$ \\
\hline FORE & & $\begin{array}{c}-1.1118^{* * *} \\
(-5.12)\end{array}$ & $\begin{array}{c}-1.1466^{* * *} \\
(-5.36)\end{array}$ & $\begin{array}{l}-1.1302^{* * *} \\
(-5.20)\end{array}$ \\
\hline \multicolumn{5}{|l|}{ Agency Cost } \\
\hline SG\&A_SALES & $\begin{array}{r}-0.0421 \\
(-1.00)\end{array}$ & & $\begin{array}{r}-0.0674 \\
(-1.02)\end{array}$ & $\begin{array}{c}-0.0414 \\
(-0.97)\end{array}$ \\
\hline SALES_ASSET & $\begin{array}{c}0.1076^{* *} \\
(2.13)\end{array}$ & & $\begin{array}{c}0.1492^{* * *} \\
(2.94)\end{array}$ & $\begin{array}{c}0.1433^{* * *} \\
(2.78)\end{array}$ \\
\hline \multicolumn{5}{|l|}{ Governance } \\
\hline BOARD_SIZE & $\begin{array}{c}0.1347^{* *} \\
(1.97)\end{array}$ & $\begin{array}{c}0.1227^{*} \\
(1.79)\end{array}$ & & $\begin{array}{c}0.1200^{*} \\
(1.75)\end{array}$ \\
\hline OUTSIDE_RATIO & $\begin{array}{r}-0.1513 \\
(-1.05)\end{array}$ & $\begin{array}{r}-0.1245 \\
(-0.86)\end{array}$ & & $\begin{array}{r}-0.1305 \\
(-0.91)\end{array}$ \\
\hline \multicolumn{5}{|l|}{ Firm-characteristics } \\
\hline NSKEW & $\begin{array}{c}-0.0579^{* *} \\
(-2.02)\end{array}$ & $\begin{array}{c}-0.0553^{*} \\
(-1.94)\end{array}$ & $\begin{array}{c}-0.0640^{* *} \\
(-2.27)\end{array}$ & $\begin{array}{c}-0.0549^{*} \\
(-1.92)\end{array}$ \\
\hline LEV & $\begin{array}{c}-0.7280^{\text {*** }} \\
(-5.71)\end{array}$ & $\begin{array}{c}-0.4677^{* * *} \\
(-3.73)\end{array}$ & $\begin{array}{c}-0.6185^{* * *} \\
(-4.82)\end{array}$ & $\begin{array}{l}-0.5959^{* * *} \\
(-4.57)\end{array}$ \\
\hline SIZE & $\begin{array}{l}-0.4825^{* * *} \\
(-23.98)\end{array}$ & $\begin{array}{l}-0.3455^{\text {**** }} \\
(-13.87)\end{array}$ & $\begin{array}{l}-0.3285^{* * * *} \\
(-13.66)\end{array}$ & $\begin{array}{l}-0.3375^{* * *} \\
(-13.49)\end{array}$ \\
\hline $\mathrm{MB}$ & $\begin{array}{c}0.1057^{* * *} \\
(6.09)\end{array}$ & $\begin{array}{c}0.0777^{* * *} \\
(4.49)\end{array}$ & $\begin{array}{c}0.0790^{* * *} \\
(4.61)\end{array}$ & $\begin{array}{l}0.0769^{* * *} \\
(4.42)\end{array}$ \\
\hline
\end{tabular}


〈표 9〉 접대비 공시의 결정요인(계속)

\begin{tabular}{lcccc}
\hline & $(1)$ & $(2)$ & $(3)$ & $(4)$ \\
\cline { 2 - 5 } & Disclosuret+1 & Disclosuret+1 & Disclosuret+1 & Disclosuret+1 \\
\hline RET & $1.6317^{* * *}$ & $1.2879^{* * *}$ & $1.4757^{* * *}$ & $1.2949^{* * *}$ \\
STD & $(4.71)$ & $(3.69)$ & $(4.40)$ & $(3.71)$ \\
& $10.3158^{* * *}$ & $6.7077^{* *}$ & $8.0309^{* * *}$ & $6.8958^{* *}$ \\
DTURN & $(3.47)$ & $(2.23)$ & $(2.75)$ & $(2.29)$ \\
& -0.9912 & -0.8808 & -0.8354 & -0.9429 \\
ABACC & $(-0.38)$ & $(-0.34)$ & $(-0.33)$ & $(-0.36)$ \\
& $-1.2316^{* * *}$ & $-1.2251^{* * *}$ & $-1.3735^{* * *}$ & $-1.2287^{* * *}$ \\
ROA & $(-4.44)$ & $(-4.46)$ & $(-5.11)$ & $(-4.46)$ \\
& $2.0231^{* * *}$ & $2.0641^{* * *}$ & $1.7893^{* * *}$ & $1.7094^{* * *}$ \\
Intercept & $(6.11)$ & $(6.58)$ & $(5.33)$ & $(5.09)$ \\
& $14.4314^{* * *}$ & $11.5065^{* * *}$ & $11.4423^{* * *}$ & $11.3230^{* * *}$ \\
Industry Dummy & $(13.30)$ & $(9.95)$ & $(10.59)$ & $(9.79)$ \\
Year Dummy & Yes & Yes & Yes & Yes \\
Observations & Yes & Yes & Yes & Yes \\
Pseudo R-squared & 15,272 & 15,270 & 15,684 & 15,268 \\
& 0.1689 & 0.1740 & 0.1746 & 0.1746 \\
\hline
\end{tabular}

<표 9>를 살펴보면, 기업지배구조의 대리변수인 재벌 더미(CH_DUM)의 계수값은 유의미한 음의 값을 갖는 것을 확인할 수 있다. 즉, 상대적으로 대리인 문제가 심각한 재벌기업에 해당할수록 접대비 공시를 하지 않는 것이다. 또한, 외국인 지분율(FORE)의 계수값도 유의미한 음의 값을 갖는 것으로 나타났는데, 이러한 결과는 외국인 투자자가 많은 경우 사익추구로 사용되는 접대비를 감추고자 하여 오히려 분리 공시하지 않는 것으로 볼 수 있다. 이에 반해, 대주주와 특수관계자 지분율의 합 $(\mathrm{OWN})$ 의 계수값은 유의미하지 않은 것으로 나타났다. 다음으로 대리인 비용의 대리변수인 판매관리비 비율(SG\&A_SALES)의 경우에는 유의성이 없었지만, 자산 회전율(SALES_ASSET)의 계수값은 유의미한 양의 값을 갖는 것으로 나타났다. 자산 회전율이 높을수록 대리인 비용은 낮아지는 것인데, 자산회전율과 접대비 분리공시의 확률이 양의 값을 가지므로, 대리인 비용이 낮을수록 접대비 분리공시의 확률이 높아지는 것이다. 기업지배구조의 대리변수인 이사회 규모(BOARD_SIZE)의 계수값은 유의미한 양의 값을 갖는 것으로 나타나, 기업지배구조가 좋은 기업일수록 접대비 분리공시를 더 많이 하는 것으로 나타났다.

종합해보면, 기업이 재벌에 해당할수록, 외국인 지분율이 높을수록 접대비 분리공시를 하지 않고, 자산회전율이 높을수록, 이사회 규모가 클수록 접대비 분리공시를 더 많이 하는 것으로 나타났다. 이러한 결과는 잠재적 대리인 문제가 심각한 기업에서는 접대비 공시를 하지 않으나, 기업지배구조가 좋고 대리인 문제가 작은 기업일수록 접대비 공시를 하고 있음을 시사한다. 


\section{5. 강건성 검증}

\section{1 헤크만 2-stage 회귀분석}

앞서 언급하였듯, 국내 기업은 손익계산서에 세부 접대비 항목을 공개할 수도 그렇지 않을 수도 있다. 따라서, 접대비 계정을 분리 공시하기로 선택한 기업의 특성은 공개하지 않기로 선택한 기업의 특성과 크게 달라 표본이 모집단을 대표하지 않는 편향(bias)이 생길 수 있다.

\section{〈표 10〉헤크만 2-stage 회귀분석}

이 표에는 헤크만 2-stage 회귀분석 결과가 제시되어 있다. $\mathrm{NSKEW}_{\mathrm{t}+1}$ 는 $\mathrm{t}+1$ 기의 기업 고유 주별 주가수익률의 왜도측정치에 (-)를 곱한 값을 의미한다. $\mathrm{DUVOL}_{\mathrm{t}+1}$ 은 $\mathrm{t}+1$ 기의 기업 고유 주별 주가수익률의 상승변동성 대비 하락변동성의 자연로그를 취한 값이다. BEE_ASSETS은 기업의 관계 형성 비용에 해당하는 접대비를 총자산으로 나눈 값이다. AFTER는 김영란법 제정 및 입법 이후(2015) 연도에는 1 의 값을, 이전 연도에는 0 의 값을 부여한 더미 변수이다. NSKEW는 $\mathrm{t}$ 기의 기업 고유 주별 주가수익률의 왜도측정치에 (-)를 곱한 값이다. $\mathrm{LEV}$ 는 총부채를 총자산으로 나눈 값이고, SIZE는 시가총액에 자연로그를 취한 값이다. $\mathrm{MB}$ 는 시장가치 자본을 장부가치 자본으로 나눈 값이다. RET는 연도별로 계산한 기업 고유 주별 주가수익률의 평균에 100 을 곱한 값이다. STD는 연도별로 계산한 기업 고유 주별 주가수익률의 표준편차이다. DTURN은 $\mathrm{t}$ 년도의 월평균 주식회전율(거래량/기말발행주식수)에서 $\mathrm{t}-1$ 년도의 월평균 주식회전율을 차감한 값이다. ABACC는 수정 존스 모형(Dechow et al., 1995)에 따라 측정한 재량적 발생액의 절댓값이다. ROA는 영업이익을 총자산으로 나눈 값이다. BOARD_SIZE는 전체 이사회 수에 자연로그를 취한 값이고, OUTSIDE_RATIO는 전체 이사회에서 사외이사가 차지하는 비율이다. $\lambda_{t}$ 는 Heckman(1979)에 따른 1단계 이항 프로빗(binary probit) 회귀분석을 통해 추정된 IMR(Invers Mill's Ratio)이라는 오류보정항이다. CH_DUM은 대규모기업집단에 해당하는 경우 1 의 값을, 그렇지 않은 경우 0 의 값을 갖는 더미 변수이다. $\mathrm{FORE}$ 는 외국인 투자자 지분율의 합이다. ${ }^{* * *}{ }^{* *},{ }^{*}$ 는 각각 $1 \%, 5 \%, 10 \%$ 의 통계적 유의 수준의 유의함을 나타낸다.

Panel A: Propensity to disclose BEEs

\begin{tabular}{lc}
\hline CH_DUM & $-0.4066(-8.80)^{* * *}$ \\
FORE & $-0.5371(-3.99)^{* * *}$ \\
NSKEW & $-0.0284(-1.57)$ \\
LEV & $-0.0367(-0.49)$ \\
SIZE & $-0.2293(-15.09)^{* * *}$ \\
MB & $0.0542(5.07)^{* * *}$ \\
RET & $0.1603(0.67)$ \\
STD & $1.2580(0.64)$ \\
DTURN & $0.8123(0.53)$ \\
ABACC & $0.1475(0.78)$ \\
ROA & $0.2998(1.45)$ \\
BOARD_SIZE & $0.1847(4.39)^{* * *}$ \\
OUTSIDE_RATIO & $-0.2128(-2.32)^{* *}$ \\
Intercept & $13.0827(19.39)^{* * *}$ \\
Industry Dummy & Yes \\
Year Dummy & Yes \\
Observations & 15,292 \\
Pseudo R-squared & 0.1626 \\
\hline
\end{tabular}


한국증권학회지 제 50 권 1호 (2021)

〈표 10〉헤크만 2-stage 회귀분석(계속)

Panel B: Heckman 2nd stage result

\begin{tabular}{|c|c|c|c|c|}
\hline & (1) & (2) & (3) & (4) \\
\hline & $\mathrm{NSKEW}_{\mathrm{t}+1}$ & $\mathrm{NSKEW}_{\mathrm{t}+1}$ & DUVOL $_{t+1}$ & DUVOL $_{t+1}$ \\
\hline \multirow[t]{2}{*}{ BEE_SALES } & $7.4905^{* * *}$ & $10.1803^{* * *}$ & $2.9992^{* * *}$ & $4.0883^{* * *}$ \\
\hline & $(4.94)$ & $(5.50)$ & $(4.53)$ & $(5.05)$ \\
\hline \multirow[t]{2}{*}{ BEE_SALES×AFTER } & & $-6.7641^{* *}$ & & $-2.7386^{* *}$ \\
\hline & & $(-2.54)$ & & $(-2.35)$ \\
\hline \multirow[t]{2}{*}{ AFTER } & & $-0.0786^{*}$ & & -0.0300 \\
\hline & & $(-1.82)$ & & $(-1.59)$ \\
\hline \multirow[t]{2}{*}{ NSKEW } & $0.0627^{* * *}$ & $0.0623^{* * *}$ & $0.0272^{* * *}$ & $0.0271^{* * *}$ \\
\hline & (6.28) & $(6.24)$ & (6.22) & (6.19) \\
\hline \multirow[t]{2}{*}{ LEV } & $0.1273^{* * *}$ & $0.1276^{* * *}$ & $0.0530^{* * *}$ & $0.0532^{* * *}$ \\
\hline & $(2.94)$ & $(2.95)$ & $(2.80)$ & $(2.81)$ \\
\hline \multirow[t]{2}{*}{ SIZE } & $0.1040^{* * *}$ & $0.1050^{* * *}$ & $0.0407^{* * *}$ & $0.0411^{* * *}$ \\
\hline & $(7.75)$ & $(7.83)$ & (6.94) & $(7.01)$ \\
\hline \multirow[t]{2}{*}{$\mathrm{MB}$} & $0.0131^{* *}$ & $0.0141^{* *}$ & $0.0062^{* *}$ & $0.0066^{* *}$ \\
\hline & (1.98) & (2.13) & $(2.13)$ & $(2.27)$ \\
\hline \multirow[t]{2}{*}{ RET } & $-0.4284^{* * *}$ & $-0.4133^{* * *}$ & $-0.2952^{* * *}$ & $-0.2891^{* * *}$ \\
\hline & $(-3.45)$ & $(-3.33)$ & $(-5.42)$ & $(-5.31)$ \\
\hline \multirow[t]{2}{*}{ STD } & $-1.8461^{*}$ & $-1.7716^{*}$ & $-1.6994^{* * *}$ & $-1.6692^{* * *}$ \\
\hline & $(-1.75)$ & $(-1.68)$ & $(-3.68)$ & $(-3.62)$ \\
\hline \multirow[t]{2}{*}{ DTURN } & 0.1688 & 0.1809 & 0.1432 & 0.1481 \\
\hline & $(0.20)$ & $(0.21)$ & $(0.38)$ & $(0.39)$ \\
\hline \multirow[t]{2}{*}{$\mathrm{ABACC}$} & $0.7343^{* * *}$ & $0.7316^{* * *}$ & $0.3550^{* * *}$ & $0.3539^{* * *}$ \\
\hline & (7.49) & $(7.47)$ & $(8.26)$ & $(8.24)$ \\
\hline \multirow[t]{2}{*}{$\mathrm{ROA}$} & $-0.4261^{* * *}$ & $-0.4254^{* * *}$ & $-0.2417^{* * *}$ & $-0.2414^{* * *}$ \\
\hline & $(-3.71)$ & $(-3.71)$ & $(-4.81)$ & $(-4.81)$ \\
\hline \multirow[t]{2}{*}{ BOARD_SIZE } & $0.0415^{*}$ & $0.0440^{*}$ & $0.0176^{*}$ & $0.0186^{*}$ \\
\hline & (1.82) & (1.93) & $(1.76)$ & (1.86) \\
\hline \multirow[t]{2}{*}{ OUTSIDE_RATIO } & $-0.1118^{* *}$ & $-0.1089^{* *}$ & $-0.0461^{* *}$ & $-0.0449^{* *}$ \\
\hline & $(-2.30)$ & $(-2.24)$ & $(-2.16)$ & $(-2.11)$ \\
\hline \multirow[t]{2}{*}{$\operatorname{Lambda}\left(\lambda_{t}\right)$} & 0.1668 & 0.1553 & $0.1016^{* *}$ & $0.0969^{* *}$ \\
\hline & $(1.57)$ & $(1.46)$ & (2.19) & $(2.08)$ \\
\hline \multirow[t]{2}{*}{ Intercept } & $13.0827^{* * *}$ & $13.0827^{* * *}$ & $13.0827^{* * *}$ & $13.0827^{* * *}$ \\
\hline & (19.39) & (19.39) & (19.39) & (19.39) \\
\hline Industry Dummy & Yes & Yes & Yes & Yes \\
\hline Year Dummy & Yes & Yes & Yes & Yes \\
\hline Observations & 15,292 & 15,292 & 15,292 & 15,292 \\
\hline
\end{tabular}

본 연구에서는 Heckman(1979) 방법을 채택하여 접대비 공개에 따른 기업의 자기선택 편향 (self-selection bias)을 해결하고자 한다. Heckman(1979)에 따르면, 1단계 이항 프로빗(binary probit) 회귀분석을 통해 $\lambda_{t}$ 로 표시된 IMR(Invers Mill's Ratio)이라는 오류보정항(error 
correction term)을 추정하고, 2 단계 회귀분석에 1 단계에서 추정된 $\lambda_{t}$ 를 포함한다. 본 연구에서는 1 단계 분석을 시행할 때 앞서 접대비 공시 결정요인을 분석한 결과에서 유의미한 영향을 미쳤던 재벌여부(CH_DUM)와 외국인지분율(FORE)을 포함한다. 앞선 분석 결과를 보면, 재벌기업에 해당할수록 접대비의 지출의 규모가 클 것임에도 불구하고 접대비 공시를 하지 않았다. 또한, 외국인 투자자가 많은 경우 사익추구로 사용될 여지가 있는 접대비 지출의 규모를 감추고자 하여 오히려 분리 공시하지 않는 것으로 나타났다. 이러한 변수들은 접대비 계정의 분리공시 여부에는 영향을 미치지만, 주가 급락위험에는 직접적으로 영향을 미치지 못하는 외생변수 (exogenous variable)가 된다.

$\lambda_{t}$ 를 추정하기 위한 <표 10>의 Panel A를 보면, 재벌여부(CH_DUM)와 외국인지분율(FORE)의 계수값은 유의미한 음의 값을 가지고 있음을 확인할 수 있다. 또한 Panel B의 모형 (1)과 (3)의 결과를 보면, 선택편향을 해결한 후에도 여전히 접대비 지출과 주가 급락위험은 유의미한 양의 관계가 있음을 확인할 수 있다. 또한, 모형 (2)와 (4)에서 접대비 지출과 주가 급락위험간의 양의 관계가 김영란법의 도입 이후 사라지는 것을 확인할 수 있으며, 이는 김영란법이 기업의 정보환경을 크게 개선했다는 것을 의미한다.

\section{2 접대비 지출과 주가 급락위험의 관계: 다른 설명변수 사용}

본 절에서는 본 연구결과의 강건성 검정을 위하여 기업의 접대비 지출 금액을 총매출액 대신 총자산으로 나누어 계산한 변수(BEE_ASSETS)를 설명변수로 사용하여 추가적인 분석을 진행하고자 한다. <표 $11>$ 의 분석결과를 살펴보면, 접대비(BEE_ASSETS)의 계수값은 유의미한 양(+)의 값을 가지고 있고, 김영란법의 입법 이후 접대비 지출이 주가 급락위험에 미치는 영향을 살펴보기 위한 교차항 BEE_ASSETS×AFTER의 계수값은 유의미한 음의 값을 가지고 있어 새로운 설명변수를 사용한 결과 $(<$ 표 $5>)$ 에서도 이전 결과와 유사함을 확인할 수 있다.

\section{3 접대비 지출과 주가 급락위험의 관계: 다른 종속변수 사용}

본 연구에서는 추가적인 강건성 검정을 위하여 종속변수를 다르게 추정하여 동일한 회귀분석을 시행하였다. 주가 급락위험을 측정하기 위해서는 확장된 시장모형 회귀식을 이용하여 잔차를 구한다. 이전에는 식 (1)과 같이 가치 가중 시장 수익률 $\left(M K R E T_{i, w}\right)$ 과 기업 $\mathrm{i}$ 가 속한 한국표준산업 분류(KSIC)의 중분류 산업의 가치 가중 수익률 $\left(I N D R E T_{i, w}\right)$ 을 포함한 시장모형을 이용하였다면, 새로운 종속변수는 가치 가중 시장 수익률 $\left(M K R E T_{i, w}\right)$ 만을 회귀식에 포함하여 추정한다.

<표 12>의 분석결과를 살펴보면, 접대비(BEE_SALES)의 계수값은 유의미한 양(+)의 값을 가지고 있고, 김영란법의 입법 이후 접대비 지출이 주가 급락위험에 미치는 영향을 살펴보기 위한 교차항 BEE_SALES $\times$ AFTER의 계수값은 유의미한 음의 값을 가지고 있다. 이러한 결과를 통해 접대비 지출을 통해 일부 이해 관계자와 관계가 너무 가까워지면 불가피하게 네트워크 외부의 주주보다 네트워크 내에서 더 많은 정보를 공유하게 되고(Granovetter, 1985; Ben et al., 2020), 정보가 비대칭인 상황에서는 정보 불투명성이 커져 내부자는 경영상의 나쁜 뉴스를 
〈표 11〉접대비 지출과 주가 급락위험: 다른 설명변수 사용

이 표에는 김영란법 제정 및 입법 이후 접대비 지출이 주가 급락위험에 미치는 영향의 회귀분석 결과가 제시되어 있다. $\mathrm{NSKEW}_{\mathrm{t}+1}$ 는 $\mathrm{t}+1$ 기의 기업 고유 주별 주가수익률의 왜도측정치에 $(-)$ 를 곱한 값을 의미한다. $\mathrm{DUVOL}_{\mathrm{t}+1}$ 은 $\mathrm{t}+1$ 기의 기업 고유 주별 주가수익률의 상승변동성 대비 하락변동성의 자연로그를 취한 값이다. BEE_ASSETS은 기업의 관계 형성 비용에 해당하는 접대비를 총자산으로 나눈 값이다. AFTER는 김영란법 제정 및 입법 이후(2015) 연도에는 1 의 값을, 이전 연도에는 0 의 값을 부여한 더미 변수이다. NSKEW는 t기의 기업 고유 주별 주가수익률의 왜도측정치에 (-)를 곱한 값이다. LEV는 총부채를 총자산으로 나눈 값이고, SIZE는 시가총액에 자연로그를 취한 값이다. $\mathrm{MB}$ 는 시장가치 자본을 장부가치 자본으로 나눈 값이다. RET는 연도별로 계산한 기업 고유 주별 주가수익률의 평균에 100 을 곱한 값이다. STD는 연도별로 계산한 기업 고유 주별 주가수익률의 표준편차이다. $\mathrm{DTURN}$ 은 $\mathrm{t}$ 년도의 월평균 주식회전율(거래량/기말발행주식수)에서 $\mathrm{t}-1$ 년도의 월평균 주식회전율을 차감한 값이다. ABACC는 수정 존스 모형(Dechow et al., 1995)에 따라 측정한 재량적 발생액의 절댓값이다. ROA는 영업이익을 총자산으로 나눈 값이다. BOARD_SIZE는 전체 이사회 수에 자연로그를 취한 값이고, OUTSIDE_RATIO는 전체 이사회에서 사외이사가 차지하는 비율이다. ${ }^{* * *}{ }^{* * *},{ }^{*}$ 는 각각 $1 \%, 5 \%, 10 \%$ 의 통계적 유의 수준의 유의함을 나타낸다.

\begin{tabular}{|c|c|c|c|c|}
\hline & (1) & (2) & (3) & (4) \\
\hline & NSKEW $_{t+1}$ & NSKEW $_{t+1}$ & DUVOL $_{t+1}$ & DUVOL $_{t+1}$ \\
\hline$\overline{\operatorname{BEE} \_\operatorname{SALES}\left(\beta_{1}\right)}$ & $\begin{array}{c}7.1460^{*} \\
(1.93)\end{array}$ & $\begin{array}{c}10.8353^{* * *} \\
(2.55)\end{array}$ & $\begin{array}{c}2.8807^{*} \\
(1.80)\end{array}$ & $\begin{array}{l}4.3957^{* *} \\
(2.34)\end{array}$ \\
\hline $\begin{array}{l}\text { BEE_SALES } \\
\times \operatorname{AFTER~}\left(\beta_{2}\right)\end{array}$ & & $\begin{array}{c}-11.7170^{*} \\
(-1.92)\end{array}$ & & $\begin{array}{c}-4.8112^{*} \\
(-1.78)\end{array}$ \\
\hline AFTER & & $\begin{array}{r}-0.0543 \\
(-1.39)\end{array}$ & & $\begin{array}{r}-0.0133 \\
(-0.80)\end{array}$ \\
\hline NSKEW & $\begin{array}{l}0.0659^{* * *} \\
(5.87)\end{array}$ & $\begin{array}{l}0.0655^{* * *} \\
(5.83)\end{array}$ & $\begin{array}{l}0.0288^{* * *} \\
(5.97)\end{array}$ & $\begin{array}{l}0.0286^{* * *} \\
(5.93)\end{array}$ \\
\hline LEV & $\begin{array}{l}0.1058^{* *} \\
(2.19)\end{array}$ & $\begin{array}{l}0.1057^{* *} \\
(2.19)\end{array}$ & $\begin{array}{l}0.0460^{* *} \\
(2.19)\end{array}$ & $\begin{array}{l}0.0459^{* *} \\
(2.19)\end{array}$ \\
\hline SIZE & $\begin{array}{l}0.1229^{* * *} \\
(15.49)\end{array}$ & $\begin{array}{l}0.1223^{* * * *} \\
(15.42)\end{array}$ & $\begin{array}{l}0.0517^{* * *} \\
(14.65)\end{array}$ & $\begin{array}{l}0.0515^{* * *} \\
(14.60)\end{array}$ \\
\hline $\mathrm{MB}$ & $\begin{array}{r}0.0100 \\
(1.38)\end{array}$ & $\begin{array}{r}0.0112 \\
(1.54)\end{array}$ & $\begin{array}{r}0.0042 \\
(1.29)\end{array}$ & $\begin{array}{r}0.0047 \\
(1.43)\end{array}$ \\
\hline RET & $\begin{array}{l}-0.4468^{* * *} \\
(-2.77)\end{array}$ & $\begin{array}{l}-0.4401^{* * *} \\
(-2.73)\end{array}$ & $\begin{array}{l}-0.3053^{* * *} \\
(-4.25)\end{array}$ & $\begin{array}{l}-0.3025^{* * *} \\
(-4.21)\end{array}$ \\
\hline STD & $\begin{array}{r}-1.8702 \\
(-1.48)\end{array}$ & $\begin{array}{r}-1.8403 \\
(-1.46)\end{array}$ & $\begin{array}{l}-1.7378^{* * * *} \\
(-3.11)\end{array}$ & $\begin{array}{l}-1.7255^{* * *} \\
(-3.09)\end{array}$ \\
\hline DTURN & $\begin{array}{r}0.1079 \\
(0.12)\end{array}$ & $\begin{array}{r}0.1094 \\
(0.12)\end{array}$ & $\begin{array}{r}0.1103 \\
(0.28)\end{array}$ & $\begin{array}{r}0.1109 \\
(0.29)\end{array}$ \\
\hline ABACC & $\begin{array}{l}0.7443^{* * *} \\
(6.13)\end{array}$ & $\begin{array}{l}0.7394^{* * *} \\
(6.09)\end{array}$ & $\begin{array}{l}0.3558^{* * *} \\
(6.51)\end{array}$ & $\begin{array}{l}0.3538^{* * *} \\
(6.48)\end{array}$ \\
\hline $\mathrm{ROA}$ & $\begin{array}{l}-0.5949^{* * * *} \\
(-4.73)\end{array}$ & $\begin{array}{l}-0.5953^{* * *} \\
(-4.73)\end{array}$ & $\begin{array}{l}-0.3128^{* * * *} \\
(-5.56)\end{array}$ & $\begin{array}{l}-0.3130 \text { **** } \\
(-5.56)\end{array}$ \\
\hline BOARD_SIZE & $\begin{array}{r}0.0367 \\
(1.41)\end{array}$ & $\begin{array}{r}0.0390 \\
(1.50)\end{array}$ & $\begin{array}{r}0.0136 \\
(1.22)\end{array}$ & $\begin{array}{r}0.0146 \\
(1.30)\end{array}$ \\
\hline OUTSIDE_RATIO & $\begin{array}{l}-0.1115^{* *} \\
(-2.25)\end{array}$ & $\begin{array}{l}-0.1073^{* * *} \\
(-2.17)\end{array}$ & $\begin{array}{l}-0.0441^{* *} \\
(-2.04)\end{array}$ & $\begin{array}{l}-0.0424^{*} \\
(-1.96)\end{array}$ \\
\hline Intercept & $\begin{array}{l}-3.2999^{* * *} \\
(-16.17)\end{array}$ & $\begin{array}{l}-3.2973^{* * *} \\
(-16.23)\end{array}$ & $\begin{array}{l}-1.3837^{* * *} \\
(-15.14)\end{array}$ & $\begin{array}{l}-1.3826^{* * *} \\
(-15.20)\end{array}$ \\
\hline Industry Dummy & Yes & Yes & Yes & Yes \\
\hline $\begin{array}{l}\text { Year Dummy } \\
\beta_{1}+\beta_{2} \\
\text { p value }\end{array}$ & Yes & $\begin{array}{r}\text { Yes } \\
-0.8817 \\
0.8704\end{array}$ & Yes & $\begin{array}{r}\text { Yes } \\
-0.4155 \\
0.8575\end{array}$ \\
\hline Observations & 12,909 & 12,909 & 12,909 & 12,909 \\
\hline Adjusted R-squared & 0.0486 & 0.0488 & 0.0506 & 0.0508 \\
\hline
\end{tabular}


Business Entertainment Expenditure and Stock Price Crashes

〈표 12〉 접대비 지출과 주가 급락위험: 다른 종속변수 사용

이 표에는 김영란법 제정 및 입법 이후 접대비 지출이 주가 급락위험에 미치는 영향의 회귀분석 결과가 제시되어 있다. $\mathrm{NSKEW}_{\mathrm{t}+1}$ 는 $\mathrm{t}+1$ 기의 기업 고유 주별 주가수익률의 왜도측정치에 (-)를 곱한 값을 의미한다. $\mathrm{DUVOL}_{\mathrm{t}+1}$ 은 $\mathrm{t}+1$ 기의 기업 고유 주별 주가수익률의 상승변동성 대비 하락변동성의 자연로그를 취한 값이다. BEE_ASSETSS은 기업의 관계 형성 비용에 해당하는 접대비를 총자산으로 나눈 값이다. AFTER는 김영란법 제정 및 입법 이후(2015) 연도에는 1 의 값을, 이전 연도에는 0 의 값을 부여한 더미 변수이다. NSKEW는 t기의 기업 고유 주별 주가수익률의 왜도측정치에 (-)를 곱한 값이다. LEV는 총부채를 총자산으로 나눈 값이고, SIZE는 시가총액에 자연로그를 취한 값이다. $\mathrm{MB}$ 는 시장가치 자본을 장부가치 자본으로 나눈 값이다. RET는 연도별로 계산한 기업 고유 주별 주가수익률의 평균에 100 을 곱한 값이다. STD는 연도별로 계산한 기업 고유 주별 주가수익률의 표준편차이다. DTURN은 t년도의 월평균 주식회전율(거래량/기말발행주식수)에서 $\mathrm{t}-1$ 년도의 월평균 주식회전율을 차감한 값이다. ABACC는 수정 존스 모형(Dechow et al., 1995)에 따라 측정한 재량적 발생액의 절댓값이다. ROA는 영업이익을 총자산으로 나눈 값이다. BOARD_SIZE는 전체 이사회 수에 자연로그를 취한 값이고, OUTSIDE_RATIO는 전체 이사회에서 사외이사가 차지하는 비율이다. ${ }^{* * *}{ }^{* * *},{ }^{*}$ 는 각각 $1 \%, 5 \%, 10 \%$ 의 통계적 유의 수준의 유의함을 나타낸다.

\begin{tabular}{|c|c|c|c|c|}
\hline & (1) & (2) & (3) & (4) \\
\hline & NSKEW $_{t+1}$ & NSKEW $_{\mathrm{t}+1}$ & DUVOL $_{t+1}$ & DUVOL $_{t+1}$ \\
\hline BEE_ASSETS $\left(\beta_{1}\right)$ & $\begin{array}{l}7.5442^{* * * *} \\
(3.70)\end{array}$ & $\begin{array}{c}10.5956^{* * *} \\
(4.34)\end{array}$ & $\begin{array}{l}3.3401^{\text {*** }} \\
(3.59)\end{array}$ & $\begin{array}{l}4.7557^{* * *} \\
(4.09)\end{array}$ \\
\hline $\begin{array}{c}\text { BEE_ASSETS } \\
\times \operatorname{AFTER}\left(\beta_{0}\right)\end{array}$ & & $\begin{array}{c}-7.6669^{* *} \\
(-2.29)\end{array}$ & & $\begin{array}{l}-3.5568^{* *} \\
(-2.30)\end{array}$ \\
\hline AFTER & & $\begin{array}{r}-0.0598 \\
(-1.49)\end{array}$ & & $\begin{array}{r}-0.0215 \\
(-1.23)\end{array}$ \\
\hline NSKEW & $\begin{array}{l}0.0617^{* * * *} \\
(5.36)\end{array}$ & $\begin{array}{l}0.0611^{* * * *} \\
(5.31)\end{array}$ & $\begin{array}{l}0.0273^{* * * *} \\
(5.45)\end{array}$ & $\begin{array}{l}0.0271^{* * *} \\
(5.40)\end{array}$ \\
\hline LEV & $\begin{array}{l}0.1397^{* * * *} \\
(2.69)\end{array}$ & $\begin{array}{l}0.1392^{* * * *} \\
(2.69)\end{array}$ & $\begin{array}{l}0.0641^{* * *} \\
(2.81)\end{array}$ & $\begin{array}{l}0.0639^{* * *} \\
(2.81)\end{array}$ \\
\hline SIZE & $\begin{array}{l}0.1222^{* * *} \\
(14.91)\end{array}$ & $\begin{array}{l}0.1221^{* * *} \\
(14.89)\end{array}$ & $\begin{array}{l}0.0499^{* * *} \\
(13.61)\end{array}$ & $\begin{array}{l}0.0499^{* * *} \\
(13.59)\end{array}$ \\
\hline $\mathrm{MB}$ & $\begin{array}{r}0.0109 \\
(1.44)\end{array}$ & $\begin{array}{r}0.0124 \\
(1.62)\end{array}$ & $\begin{array}{r}0.0048 \\
(1.37)\end{array}$ & $\begin{array}{r}0.0054 \\
(1.55)\end{array}$ \\
\hline RET & $\begin{array}{l}-0.5242^{* * *} \\
(-3.19)\end{array}$ & $\begin{array}{l}-0.5062^{* * *} \\
(-3.09)\end{array}$ & $\begin{array}{l}-0.3595^{* * *} \\
(-4.76)\end{array}$ & $\begin{array}{l}-0.3512^{* * *} \\
(-4.67)\end{array}$ \\
\hline STD & $\begin{array}{l}-2.3404^{*} \\
(-1.78)\end{array}$ & $\begin{array}{l}-2.2426^{*} \\
(-1.71)\end{array}$ & $\begin{array}{l}-2.1027^{* * *} \\
(-3.54)\end{array}$ & $\begin{array}{l}-2.0573^{* * *} \\
(-3.48)\end{array}$ \\
\hline DTURN & $\begin{array}{r}0.0827 \\
(0.09)\end{array}$ & $\begin{array}{r}0.1005 \\
(0.11)\end{array}$ & $\begin{array}{r}0.1670 \\
(0.42)\end{array}$ & $\begin{array}{r}0.1753 \\
(0.44)\end{array}$ \\
\hline ABACC & $\begin{array}{l}0.8013^{* * * *} \\
(6.03)\end{array}$ & $\begin{array}{l}0.7986^{* * * *} \\
(6.02)\end{array}$ & $\begin{array}{l}0.3918^{* * * *} \\
(6.40)\end{array}$ & $\begin{array}{l}0.3905^{* * *} \\
(6.40)\end{array}$ \\
\hline ROA & $\begin{array}{l}-0.4840^{* * * *} \\
(-3.54)\end{array}$ & $\begin{array}{l}-0.4810^{* * * *} \\
(-3.52)\end{array}$ & $\begin{array}{l}-0.2704^{* * * *} \\
(-4.37)\end{array}$ & $\begin{array}{l}-0.2690^{* * * *} \\
(-4.35)\end{array}$ \\
\hline BOARD_SIZE & $\begin{array}{r}0.0340 \\
(1.24)\end{array}$ & $\begin{array}{r}0.0376 \\
(1.37)\end{array}$ & $\begin{array}{r}0.0108 \\
(0.88)\end{array}$ & $\begin{array}{r}0.0124 \\
(1.02)\end{array}$ \\
\hline OUTSIDE_RATIO & $\begin{array}{l}-0.1208^{* *} \\
(-2.39)\end{array}$ & $\begin{array}{l}-0.1180^{* *} \\
(-2.34)\end{array}$ & $\begin{array}{l}-0.0532^{* *} \\
(-2.38)\end{array}$ & $\begin{array}{l}-0.0519^{* *} \\
(-2.32)\end{array}$ \\
\hline Intercept & $\begin{array}{l}-3.3374^{* * *} \\
(-14.65)\end{array}$ & $\begin{array}{l}-3.3499^{* * *} \\
(-14.89)\end{array}$ & $\begin{array}{l}-1.3493^{* * *} \\
(-13.30)\end{array}$ & $\begin{array}{l}-1.3550^{* * *} \\
(-13.52)\end{array}$ \\
\hline Industry Dummy & Yes & Yes & Yes & Yes \\
\hline Year Dummy & Yes & Yes & Yes & Yes \\
\hline$\beta_{1}+\beta_{2}$ & & 2.9287 & & 1.1989 \\
\hline p_value & & 0.3066 & & 0.3396 \\
\hline Observations & 12,908 & 12,908 & 12,908 & 12,908 \\
\hline Adjusted R-squared & 0.0521 & 0.0526 & 0.0551 & 0.0556 \\
\hline
\end{tabular}

106 
한국증권학회지 제 50 권 1 호 (2021)

저장하는 행위를 촉진하게 될 것이기에 주가 급락위험이 증가하고, 김영란법의 도입은 이러한 양의 영향을 크게 완화함을 확인할 수 있다.

\section{6. 결론}

본 연구에서는 기업의 접대비 지출이 주가 급락위험에 미치는 영향을 살펴본다. 만약 접대비 지출을 통한 기업의 관계 형성을 위한 노력이 정보 투명성을 증대시키고 정보의 흐름을 원활하게 하여 이해관계자들의 신뢰를 얻는 기회가 된다면 주가 급락위험은 감소할 수 있고(신뢰형성 견해), 반대로 만약 관계형성비용의 증대가 불투명성를 통해 나쁜 정보의 축적과 관계가 있다면 주가 급락위험은 증가할 수 있다(대리인 문제 견해). 이처럼 재량적 지출인 접대비를 보는 시각에 따라 상반되는 예측이 존재하므로, 본 연구에서는 접대비 지출이 미래 주가 급락위험에 미치는 영향을 조사하여, 접대비 지출의 실질적인 동기를 살펴보고자 한다.

분석결과, 기업의 접대비 지출이 증가할수록 주가 급락위험은 증가하는 것으로 나타나, 국내 기업의 접대비 지출은 대리인 문제(agency problem) 가설을 지지하는 것으로 확인되었다. 접대비 지출을 통해 일부 이해 관계자와 관계가 너무 가까워지면 불가피하게 네트워크 외부의 주주보다 네트워크 내에서 더 많은 정보를 공유하게 되고(Granovetter, 1985; Ben et al., 2020), 정보가 비대칭인 상황에서는 정보 불투명성이 커져 내부자는 경영상의 나쁜 뉴스를 저장하는 행위를 촉진하게 될 것이기에, 결과적으로 주가 급락이 증가하게 되는 것이다. 아울러, 본 연구에서는 접대비 지출에 영향을 줄 김영란법의 입법 및 제정으로 인하여 기업의 접대비가 주가 급락위험에 미치는 양 $(+)$ 의 영향을 유의미하게 감소시킴을 확인하였다. 이러한 결과를 통해 김영란법과 같은 부정청탁금지법이 경영 투명성을 증대시켜 기업을 둘러싼 정보환경을 개선하고, 결과적으로 대리인 문제를 감소시키는 효과가 있음을 확인하였다.

한편, 우리나라에서 접대비는 재무제표 의무공시 사항이 아니므로 접대비 계정의 공시는 선택적으로 이루어질 수 있다. 만약 접대비를 내부자의 사적 이익을 추구하기 위해서 사용하고자 한다면 그들은 접대비 공시를 선택적으로 하지 않을 수 있다. 따라서 본 연구에서는 기업들의 접대비 공시가 어떤 요인에 의해서 이루어질 수 있는지 분석하고자 한다. 분석결과, 기업이 재벌에 해당할수록, 외국인 지분율이 높을수록 접대비 분리공시를 하지 않으며, 자산회전율이 높을수록, 이사회 규모가 클수록 접대비 분리공시를 더 많이 하는 것으로 나타났다. 이러한 결과는 잠재적 대리인 문제가 큰 기업에서는 접대비 공시를 하지 않으나, 상대적으로 기업지배 구조가 좋고 대리인 문제가 작은 기업일수록 접대비 공시를 하고 있음을 시사한다. 
Business Entertainment Expenditure and Stock Price Crashes

\section{References}

Acemoglu, D., and T. Verdier, 2000, The Choice between Market Failures and Corruption, American Economic Review, Vol. 90 (1), pp. 194-211.

Ang, J. S., R. A. Cole, and J. W. Lin, 2000, Agency Costs and Ownership Structure, The Journal of Finance, Vol. 55 (1), pp. 81-106.

Ben, J. H., X. Li, K. Duncan, and J. Xu, 2020, Corporate Relationship Spending and Stock Price Crash Risk: Evidence from China's Anti-Corruption Campaign, Journal of Banking and Finance, Vol. 113, pp. 105758.

Brenkert, G. G., 1998, Trust, Business and Business Ethics: An Introduction, Business Ethics Quarterly, Vol. 8 (2), pp. 195-203.

Cai, H., H. Fang, and L. C. Xu, 2011, Eat, Drink, Firms, Government: An Investigation of Corruption from the Entertainment and Travel Costs of Chinese Firms, The Journal of Law and Economics, Vol. 54 (1), pp. 55-78.

Cao, C., C. Xia, and K. C. Chan, 2016, Social Trust and Stock Price Crash Risk: Evidence from China, International Review of Economics and Finance, Vol. 46, pp. 148-165.

Chen, J., H. Hong, and J. C. Stein, 2001, Forecasting Crashes: Trading Volume, Past Returns, and Conditional Skewness in Stock Prices, Journal of Financial Economics, Vol. 61 (3), pp. 345-381.

Chen, Y., M. Liu, and J. Su, 2013, Greasing the Wheels of Bank Lending: Evidence from Private Firms in China, Journal of Banking and Finance, Vol. 37 (7), pp. 2533-2545.

Choi, B., D. Moon, and J. Byun, 2019, The Effect of Entertainment Expenditures Related Rules on Revenue Relevance of Entertainment Expenses, Korean Accounting Review, Vol. 44 (3), pp. 37-66.

Choi, S. H., and M. T. Kim, 2017, The Effect of Internal Accounting Management System on Entertainment Expenses, Korean Accounting Journal, Vol. 26 (3), pp. 105-139.

Choi, W. W., K. S. Kim, and Y. H. Lee, 2005, An Empirical Study on Revenue Contribution of Meals \& Entertainment Expenditure in Excess of Corporate Tax Deduction Limit, Korean Journal of Taxation Research, Vol. 22 (4), pp. 87-121.

Claessens, S., S. Djankov, and L. H. Lang, 2000, The Separation of Ownership and Control in East Asian Corporations, Journal of Financial Economics, Vol. 58 (1-2), pp. 81-112.

Dechow, P. M., and I. D. Dichev, 2002, The Quality of Accruals and Earnings: The Role of Accrual Estimation Errors, The Accounting Review, Vol. 77 (s-1), pp. 35-59.

DeFond, M. L., T. J. Wong, and S. Li, 1999, The Impact of Improved Auditor Independence on Audit Market Concentration in China, Journal of Accounting and Economics, Vol. 28 (3), pp. 269-305. 
한국증권학회지 제 50 권 1 호 (2021)

Donaldson, T., and L. E. Preston, 1995, The Stakeholder Theory of the Corporation: Concepts, Evidence, and Implications, Academy of Management Review, Vol. 20 (1), pp. 65-91. Engelberg, J., P. Gao, and C. A. Parsons, 2012, Friends with Money, Journal of Financial Economics, Vol. 103 (1), pp. 169-188.

Fang, X., J. Pittman, and Y. Zhao, 2021, The Importance of Director External Social Networks to Stock Price Crash Risk, Contemporary Accounting Research, Forthcoming.

Firth, M., K. Wang, and S. M. Wong, 2015, Corporate Transparency and the Impact of Investor Sentiment on Stock Prices, Management Science, Vol. 61 (7), pp. 1630-1647.

Freeman, R. E., A. C. Wicks, and B. Parmar, 2004, Stakeholder Theory and "The Corporate Objective Revisited", Organization Science, Vol. 15 (3), pp. 364-369.

Freeman, R. E., Strategic Management: A Stakeholder Approach, Cambridge University Press, Cambridge, U.K., 2010.

Gopalan, R., and S. Jayaraman, 2012, Private Control Benefits and Earnings Management: Evidence from Insider Controlled Firms, Journal of Accounting Research, Vol. 50 (1), pp. 117-157.

Granovetter, M., 1985, Economic Action and Social Structure: The Problem of Embeddedness, American Journal of Sociology, Vol. 91 (3), pp. 481-510.

Granovetter, M., 2005, The Impact of Social Structure on Economic Outcomes, Journal of Economic Perspective, Vol. 19 (1), pp. 33-50.

Harvey, C. R., and A. Siddique, 2000, Conditional Skewness in Asset Pricing Tests, The Journal of Finance, Vol. 55 (3), pp. 1263-1295.

Haythornthwaite, C., 1996, Social Network Analysis: An Approach and Technique for the Study of Information Exchange, Library and Information Science Research, Vol. 18 (4), pp. 323-342.

Heckman, J., 1979, Sample Selection Bias as a Specification Error, Econometrica, Vol. 47 (1), pp. 153161.

Hong, H., and J. C. Stein, 2003, Differences of Opinion, Short-Sales Constraints, and Market Crashes, The Review of Financial Studies, Vol. 16 (2), pp. 487-525.

Hutton, A. P., A. J. Marcus, and H. Tehranian, 2009, Opaque Financial Reports, $R^{2}$, and Crash Risk, Journal of Financial Economics, Vol. 94 (1), pp. 67-86.

Im, J., and W. Kim, A Bribe and Corporate Performance: Causal Evidence from a Quasi-Natural Experiment, Working paper, 2019, http://ssrn.com/abstract_id=3688874

Jackson, M. O., B. W. Rogers, and Y. Zenou, 2017, The Economic Consequences of Social-Network Structure, Journal of Economic Literature, Vol. 55 (1), pp. 49-95.

Jin, L., and S. C. Myers, 2006, $\mathrm{R}^{2}$ Around the World: New Theory and New Tests, Journal of Financial Economics, Vol. 79 (2), pp. 257-292. 
Business Entertainment Expenditure and Stock Price Crashes

Jones, T. M., 1995, Instrumental Stakeholder Theory: A Synthesis of Ethics and Economics, Academy of Management Review, Vol. 20 (2), pp. 404-437.

Khwaja, A. I., and A. Mian, 2005, Do Lenders Favor Politically Connected Firms? Rent Provision in an Emerging Financial Market, The Quarterly Journal of Economics, Vol. 120 (4), pp. 1371-1411.

Kim, J. B., and L. Zhang, 2014, Financial Reporting Opacity and Expected Crash Risk: Evidence from Implied Volatility Smirks, Contemporary Accounting Research, Vol. 31 (3), pp. 851-875.

Kim, J. B., and L. Zhang, 2016, Accounting Conservatism and Stock Price Crash Risk: Firm Level Evidence, Contemporary Accounting Research, Vol. 33 (1), pp. 412-441.

Kim, J. B., Y. Li, and L. Zhang, 2011a, CFOs versus CEOs: Equity Incentives and Crashes, Journal of Financial Economics, Vol. 101 (3), pp. 713-730.

Kim, J. B., Y. Li, and L. Zhang, 2011b, Corporate Tax Avoidance and Stock Price Crash Risk: Firm-level Analysis, Journal of Financial Economics, Vol. 100 (3), pp. 639-662.

Kim, S., and M. Kim, 2011, The Effects of Firms' Contribution Expenses and Catering Expenses on Their Profitability in Korea: Theory and Evidence, Korean Academic Society of Business Administration, Vol. 40 (3), pp. 659-685.

Kothari, S. P., S. Shu, and P. D. Wysocki, 2009, Do Managers Withhold Bad News?, Journal of Accounting Research, Vol. 47 (1), pp. 241-276.

Lee, T. J., 2009, An Empirical Study on Firm's Revenue of Meals \& Entertainment Expenditures, Journal of Business Research, Vol. 24, pp. 191-209.

Leuz, C., D. Nanda, and P. D. Wysocki, 2003, Earnings Management and Investor Protection: An International Comparison, Journal of Financial Economics, Vol. 69 (3), pp. 505-527.

Li, X., S. S. Wang, and X. Wang, 2017, Trust and Stock Price Crash Risk: Evidence from China, Journal of Banking and Finance, Vol. 76, pp. 74-91.

Liu, X., 2016, Corruption Culture and Corporate Misconduct, Journal of Financial Economics, Vol. 122 (2), pp. 307-327.

Mauro, P., 1995, Corruption and Growth, The Quarterly Journal of Economics, Vol. 110 (3), pp. 681-712.

Morck, R., and M. Nakamura, 1999, Banks and Corporate Control in Japan, The Journal of Finance, Vol. 54 (1), pp. 319-339.

Park, H. J., H. H. Shin, and W. S. Choi, 2004, The Korean Firms' Agency Costs and Firm Value: Role of Foreign Investors' Equity Ownership, Korean Academic Society of Business Administration, Vol. 33 (2), pp. 655-682. 
한국증권학회지 제 50 권 1호 (2021)

Park, J., and M. Y. Lee, 2003, A Bankruptcy Prediction Model Using Ethical Variables Focused on Reception Expenses and Welfare Expenses, Korean Academic Society of Business Administration, Vol. 32 (2), pp. 499-522.

Petersen, M. A., 2009, Estimating Standard Errors in Finance Panel Data Sets: Comparing Approaches, The Review of Financial Studies, Vol. 22 (1), pp. 435-480.

Piotroski, J. D., and D. T. Roulstone, 2004, The Influence of Analysts, Institutional Investors, and Insiders on the Incorporation of Market, Industry, and Firm-Specific Information into Stock Prices, The Accounting Review, Vol. 79 (4), pp. 1119-1151.

Singh, M., and W. N. Davidson III, 2003, Agency Costs, Ownership Structure and Corporate Governance Mechanisms, Journal of Banking and Finance, Vol. 27 (5), pp. 793-816.

Sun, F., 2016, How to Manage Client Entertainment in China, Business Horizons, Vol. 59 (4), pp. 401-410.

Woo, Y. S., 2015, The Effect of Tax Avoidance on Managerial Perquisite Consumption, Korean Association for Accounting and Policy, Vol. 20 (2), pp. 87-119.

Yafeh, Y., and O. Yosha, 2003, Large Shareholders and Banks: Who Monitors and How?, The Economic Journal, Vol. 113 (484), pp. 128-146.

Yoon, M. J., and J. Hyeon, 2020, The Effect of Improper Solicitation and Graft Act on Cost Stickiness, Korea Tax Research Forum, Vol. 20 (2), pp. 163-186. 